Check for updates

Cite this: Chem. Sci., 2019, 10, 594

O All publication charges for this article have been paid for by the Royal Society of Chemistry

Received 15th August 2018

Accepted 18th October 2018

DOI: $10.1039 / \mathrm{c} 8 \mathrm{sc} 03636 \mathrm{e}$

rsc.li/chemical-science

\section{Rational molecular design for realizing high performance sky-blue-emitting gold(III) complexes with monoaryl auxiliary ligands and their applications for both solution-processable and vacuum-deposited organic light-emitting devices}

\author{
Man-Chung Tang, Wing-Kei Kwok, Shiu-Lun Lai, Wai-Lung Cheung, \\ Mei-Yee Chan (D)* and Vivian Wing-Wah Yam (D)*
}

\begin{abstract}
A new class of sky-blue-emitting arylgold(III) complexes containing tridentate bis-cyclometalating ligands derived from 2,6-diphenylpyridine $\left(C^{\wedge} N^{\wedge} C\right)$ has been successfully designed and synthesized. By systematically varying the electron-withdrawing groups from cyano, fluoro, and trifluoromethyl to trifluoromethoxy groups on the phenyl ring of the tridentate $C^{\wedge} N^{\wedge} C$ ligands, the emission maxima of these complexes have been significantly blue-shifted from $492 \mathrm{~nm}$ to $466 \mathrm{~nm}$ in dichloromethane solution. In addition, the higher excited state distortion with respect to the ground state associated with the multiple fluoro substitutions at the tridentate ligand has been successfully reduced by the employment of trifluoromethyl and trifluoromethoxy groups, as revealed by the Huang-Rhys factor. Taking advantage of their high photoluminescence quantum yields of up to $43 \%$ in the solid-state MCP thin-films, high performance solution-processable and vacuum-deposited organic light-emitting devices with external quantum efficiencies of up to $5.3 \%$ and $11.3 \%$, respectively, have been realized. This work represents the first demonstration of sky-blue-emitting gold(III) complexes with an $x$ chromaticity coordinate of $<0.2$.
\end{abstract}

\section{Introduction}

With the successful launching of high resolution mobile phones and television displays on the market, recent developments have turned organic light-emitting devices (OLEDs) into a practical reality with unprecedented success. ${ }^{1-5}$ The advancement in the design of high-performance luminescent materials as well as smart device architecture has led to a leap-forward development for the display industry. To realize full-color displays, emitters with emission energies covering the whole visible region from saturated blue to saturated red are required. Among the RGB colors, the development of blue-emitting materials with emission in the blue region at $c a .400-480 \mathrm{~nm}$ is still one of the most challenging tasks. Rapid progress in device performance with extraordinary high external quantum efficiencies (EQEs) has been demonstrated for blue emission in recent years. ${ }^{6,7}$ Of particular interest are thermally activated delayed fluorescence (TADF) and phosphorescent materials, because of their capabilities to harvest all singlet and triplet excitons. Notably, Adachi and co-workers have reported high performance blue-emitting TADF materials with nearly $100 \%$

Department of Chemistry, The University of Hong Kong, Pokfulam Road, Hong Kong, P. R. China.E-mail: wwyam@hku.hk; chanmym@hku.hk; Fax:+86 8522857 1586; Tel: +8685228592153 internal quantum efficiencies. ${ }^{8}$ Efficient vacuum-deposited OLEDs with EQEs of up to $25.9 \%$ have also been realized although the relatively long excited lifetimes of the TADF materials have inevitably resulted in severe triplet-triplet annihilation at high brightness. ${ }^{8}$

Meanwhile, blue-emitting phosphorescent complexes, mostly based on iridium(III) and platinum(II) systems, with good color purities and outstanding electroluminescence (EL) performances with EQEs of up to $30 \%$ have been demonstrated. ${ }^{9-13}$ Typically, the incorporation of high triplet energy cyclometalating ligands or carbene-type ligands is the most effective way to blue-shift the emission. ${ }^{14-18}$ In particular, a number of blue-emitting phosphors based on iridium(III) and platinum(II) metal centers have been reported; for example, deep blue-emitting phosphorescent OLEDs (PHOLEDs) based on iridium(III) complexes with picolinic acid $N$ oxide as the auxiliary ligand were reported by Kim and coworkers. ${ }^{19}$ High EQEs of $23.3 \%$ and Commission Internationale de L'Eclairage (CIE) coordinates of $(0.15,0.20)$ have been realized via smart device engineering. ${ }^{19}$ Meanwhile, Li and co-workers reported a series of deep blue-emitting phosphorescent $\mathrm{C}^{\wedge} \mathrm{C}^{\wedge} \mathrm{C}^{\wedge} \mathrm{N}$ tetradentate-ligand containing platinum(II) complexes. ${ }^{20}$ PHOLEDs based on these complexes exhibited a maximum EQE of $23.7 \%$ with CIE coordinates of $(0.14,0.15)$. 
Compared to the isoelectronic platinum(II) analogues with a square-planar structure, there are only a handful of phosphorescent gold(III) complexes that have been reported to emit in the blue region. ${ }^{21}$ The occurrence of red-shifted excimeric emission, which is commonly observed in $\mathrm{d}^{8}$ square-planar metal complexes, may be one of the most important key factors for the synthetic challenges for blue-emitting gold(III) complexes. ${ }^{22}$ Besides, our recent demonstrations on the design of new classes of high performance cyclometalated gold(III) complexes with bidentate, tridentate and tetradentate ligands have provided inspiration for the strategy for further modification of this system. ${ }^{23-34}$ In particular, arylgold(III) complexes appear to be an ideal candidate for further development of a versatile design strategy for blue-emitting gold(III) complexes, where the steric interactions between the auxiliary aryl ring and the 2,6-diphenylpyridine $\left(\mathrm{C}^{\wedge} \mathrm{N}^{\wedge} \mathrm{C}\right)$ ligand can effectively suppress the $\pi$-stacking. ${ }^{35}$ To further blue-shift the emission energy, herein we report a novel class of sky-blue-emitting arylgold(III) complexes 1-7 by incorporating different tridentate ligands derived from the $\mathrm{C}^{\wedge} \mathrm{N}^{\wedge} \mathrm{C}$ ligand (Scheme 1). Particularly, the $4,4^{\prime}$-positions of the phenyl ring of the tridentate ligand have been changed to an electron-withdrawing cyano and electron-donating tert-butyl groups in $\mathbf{1}$, fluoro and tert-butyl groups in 2 , while complex 3 is 4 -fluoro- and $3^{\prime}, 5^{\prime}$ difluoro-substituted and complex 4 is tetrafluoro-substituted at $3,3^{\prime}, 5,5^{\prime}$-positions. By varying their electron-withdrawing substituents as well as the positions of the phenyl ring of the tridentate ligand, the emission maxima of the complexes, i.e. $\mathbf{1 - 4}$, are found to be progressively blue-shifted from $492 \mathrm{~nm}$ to $466 \mathrm{~nm}$. By replacing the $4,4^{\prime}$-positions of the phenyl ring by other stronger electron-withdrawing groups, i.e. trifluoromethyl in 6 and trifluoromethoxy in 7, the CIE coordinates can be further blue-shifted from $(0.22,0.43)$ in 4 to $(0.22,0.42)$ in 5 , $(0.21,0.42)$ in 6 , and $(0.19,0.39)$ in 7 in the solution state. In addition to their high photoluminescence quantum yields (PLQYs) of up to $43 \%$ in doped $N, N^{\prime}$-dicarbazolyl-3,5-benzene (MCP) thin films, this class of arylgold(III) complexes is highly soluble in common organic solvents and is thermally evaporable, allowing them to serve as phosphorescent dopants for both solution-processable and vacuum-deposited OLEDs. Remarkable EQEs of up to $11.3 \%$ with a peak wavelength of $476 \mathrm{~nm}$ and CIE coordinates of $(0.19,0.43)$ have been achieved, demonstrating that the emission of arylgold(III) complexes can span over the entire visible region into the blue region and their broad color-tuning ability is comparable to that of state-of-theart iridium(III) and platinum(II) counterpart systems.

\section{Results and discussion}

\section{Synthesis of arylgold(III) complexes}

The synthetic route and molecular structures of complexes 1-7 are shown in Scheme 1. Complexes 1-7 are prepared via modification of the literature procedure for bis-cyclometalated arylgold(III) complexes. ${ }^{36,37}$ The identities of all the complexes have been confirmed by ${ }^{1} \mathrm{H}$ and ${ }^{13} \mathrm{C}$ NMR spectroscopy, FAB mass spectrometry and elemental analyses. These complexes have been isolated as thermally stable white to pale yellow solids with high decomposition temperatures $\left(T_{\mathrm{d}}\right)$ of $>290{ }^{\circ} \mathrm{C}$ (Table 1). The thermogravimetric traces of selected complexes have been shown in Fig. 1.

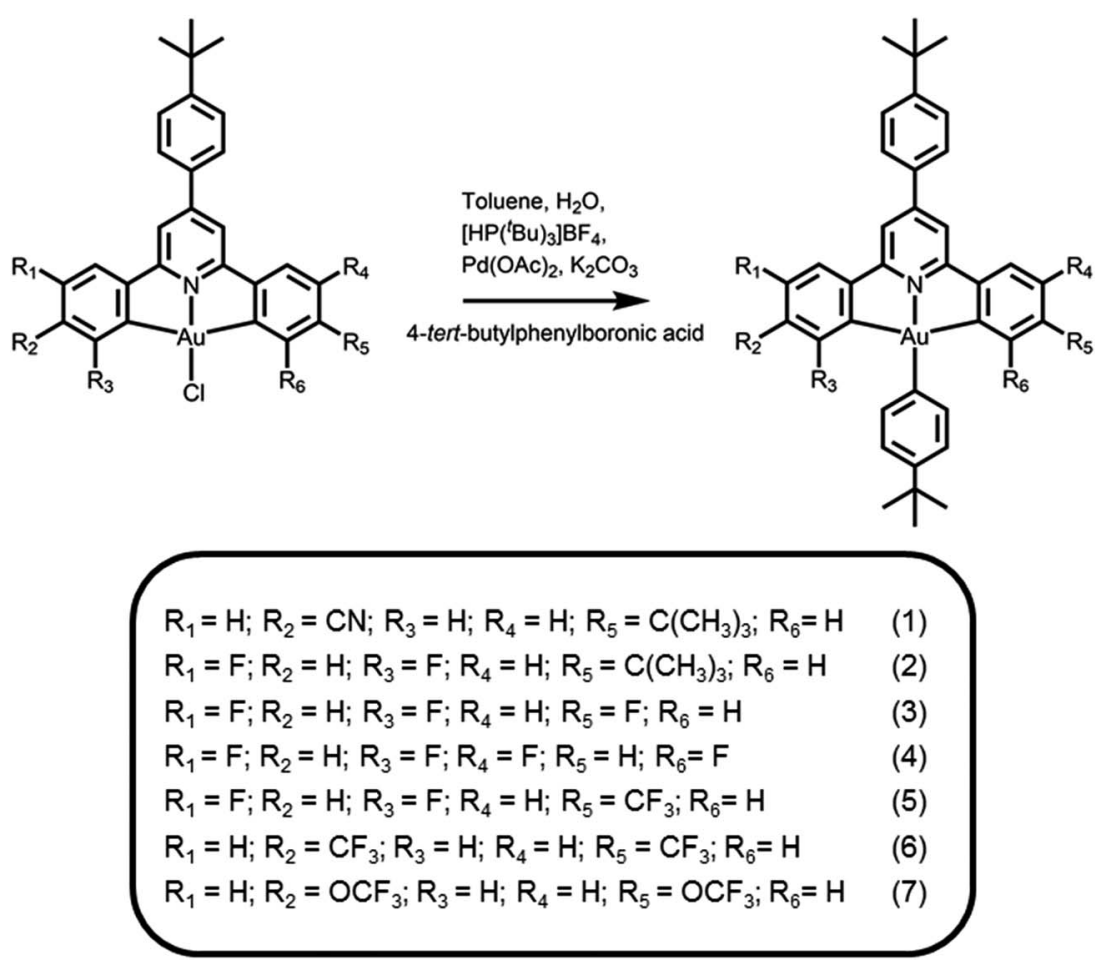

Scheme 1 Synthetic route and molecular structures of cyclometalated arylgold(III) complexes. 
Table 1 Thermal properties of complexes 1-7

\begin{tabular}{cc}
\hline Complex & $T_{\mathrm{d}}{ }^{a} /{ }^{\circ} \mathrm{C}$ \\
\hline $\mathbf{1}$ & 344 \\
$\mathbf{2}$ & 310 \\
$\mathbf{3}$ & 296 \\
$\mathbf{4}$ & 325 \\
$\mathbf{5}$ & 304 \\
$\mathbf{6}$ & 293 \\
$\mathbf{7}$ & 315
\end{tabular}

${ }^{a} T_{\mathrm{d}}$ is defined as the temperature at which the material showed a $5 \%$ weight loss.

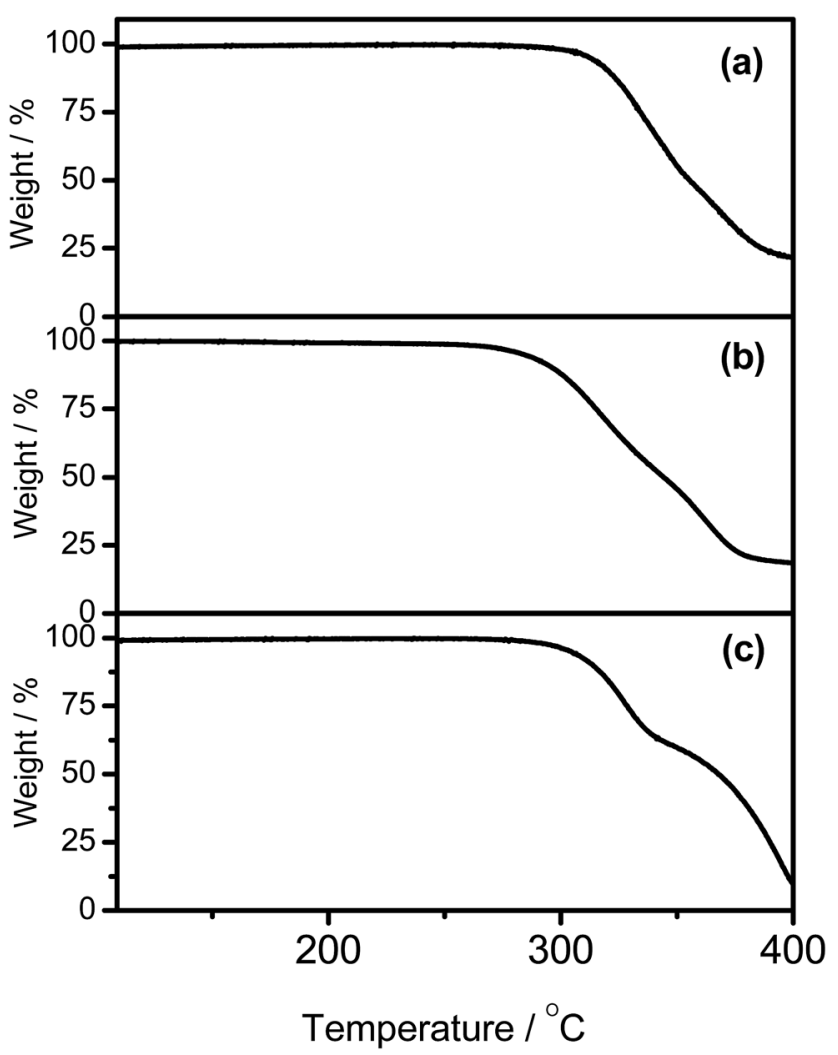

Fig. 1 Thermogravimetric analysis (TGA) curves of (a) 1, (b) 2, and (c) 5

\section{Photophysical properties}

All the complexes show intense absorption bands at ca. 280$320 \mathrm{~nm}$ with a moderately intense vibronic-structured band at ca. 360-410 nm with extinction coefficients $(\varepsilon)$ on the order of $10^{4} \mathrm{dm}^{3} \mathrm{~mol}^{-1} \mathrm{~cm}^{-1}$. Table 2 summarizes the photophysical data of 1-7. The UV-vis absorption and emission spectra of complexes 1-7 in dichloromethane at $298 \mathrm{~K}$ are shown in Fig. 2 and 3 , respectively. The low-energy absorption shoulder is found to be sensitive to the substituent groups on the phenyl moiety of the $\mathrm{C}^{\wedge} \mathrm{N}^{\wedge} \mathrm{C}$ ligand, and has been tentatively assigned as the metal-perturbed intraligand (IL) $\pi \rightarrow \pi^{*}$ transition of the $\mathrm{C}^{\wedge} \mathrm{N}^{\wedge} \mathrm{C}$ ligand with IL charge transfer (ILCT) character from the phenyl ring to the pyridine unit, possibly with mixing of some ligand-to-ligand charge transfer (LLCT) transition from the aryl ligand to the pyridine unit of the $\mathrm{C}^{\wedge} \mathrm{N}^{\wedge} \mathrm{C}$ ligand. ${ }^{35-37}$ A progressive blue shift of the low-lying absorption bands at $c a .384$ and $404 \mathrm{~nm}$ in 1 to $c a .366$ and $386 \mathrm{~nm}$ in 4 is observed, attributed to the stronger electron-withdrawing effect of the fluorine substituents than that of the cyano group. In addition, on going from 4 to 7 , it is revealed that the incorporation of trifluoromethyl or trifluoromethoxy at the 4-position of the phenyl ring of the tridentate ligand could exert a similar electronic effect to 3,5-difluoro-substitution. It is worth noting that such modification of the substituent groups on the phenyl ring can also affect the emission energies of this class of gold(III) complexes. Upon excitation at $\lambda \geq 350 \mathrm{~nm}$ in degassed dichloromethane solution at $298 \mathrm{~K}$, a vibronic-structured band with an emission maximum at ca. 466-492 $\mathrm{nm}$ has been observed for 1-7. The emission energies are found to be dependent on the nature of the tridentate ligand and have been assigned as originating from the metal-perturbed ${ }^{3} \mathrm{IL}[\pi \rightarrow$ $\left.\pi^{*}\left(\mathrm{C}^{\wedge} \mathrm{N}^{\wedge} \mathrm{C}\right)\right]$ state, with some aryl-to-pyridine ${ }^{3}$ ILCT character. ${ }^{35-37}$ In parallel to the UV-vis studies, the emission wavelength maximum has been blue-shifted with increasing number of the fluorine atoms on the phenyl moiety of the $\mathrm{C}^{\wedge} \mathrm{N}^{\wedge} \mathrm{C}$ ligand, i.e. $1(492 \mathrm{~nm})>2(474 \mathrm{~nm})>3(470 \mathrm{~nm})>\mathbf{4}(466 \mathrm{~nm})$ (Fig. 3a). Unfortunately, the emission band shape has been found to be sensitive to multiple substitutions of fluorine atoms on the $\mathrm{C}^{\wedge} \mathrm{N}^{\wedge} \mathrm{C}$ ligand, which perturbs the relative transition probability of the vibronic bands, as governed by the vibrational wavefunction overlap between the excited state and the ground state, commonly known as the Franck-Condon overlap integral, which is associated with the Franck-Condon factor. ${ }^{38-40}$ Specifically, the Huang-Rhys factor $(S)$, which is defined as the ratio of the vibronic $(1,0)$ and $(0,0)$ intensities, serves to quantify the structural distortion $\Delta Q$ of the excited states with respect to the ground state. ${ }^{39}$ Tetrafluoro substitution on the phenyl ring of the $\mathrm{C}^{\wedge} \mathrm{N}^{\wedge} \mathrm{C}$ ligand has resulted in a larger excited state distortion of 4 , as revealed by a Huang-Rhys factor of $>1$ (Fig. 3a). Interestingly, upon replacing the fluorine atoms by either one or two stronger electron-withdrawing trifluoromethyl and trifluoromethoxy groups (i.e. 5-7) according to the Hammett constant, ${ }^{41}$ the ratio of the vibronic $(1,0)$ and $(0,0)$ intensities of 5 and 6 becomes closer and even comparable in the case of 7 (Fig. 3b), indicating that the Huang-Rhys factor is approaching 1. More importantly, the higher emission color purity can be reflected by their emissions in MCP thin films. For instance, all the complexes feature vibronic-structured emission bands with peak maxima at $c a .474-498 \mathrm{~nm}$; the thin film emission spectra of $\mathbf{4}$ doped with different concentrations are illustrated in Fig. 4. The emission energies are found to be independent of the dopant concentration in MCP thin films, without the presence of any undesirable excimeric emission arising from the $\pi-\pi$ stacking of the $\mathrm{C}^{\wedge} \mathrm{N}^{\wedge} \mathrm{C}$ ligand, which is in contrast to those commonly observed in square-planar $\mathrm{d}^{8}$ metal complexes..$^{23,24,26}$

\section{Electrochemistry}

The electrochemical data of 1-7 in dichloromethane solution (0.1 $\mathrm{M}^{n} \mathrm{Bu}_{4} \mathrm{NPF}_{6}$ ) have been measured by cyclic voltammetry 
Table 2 Photophysical properties of complexes 1-7

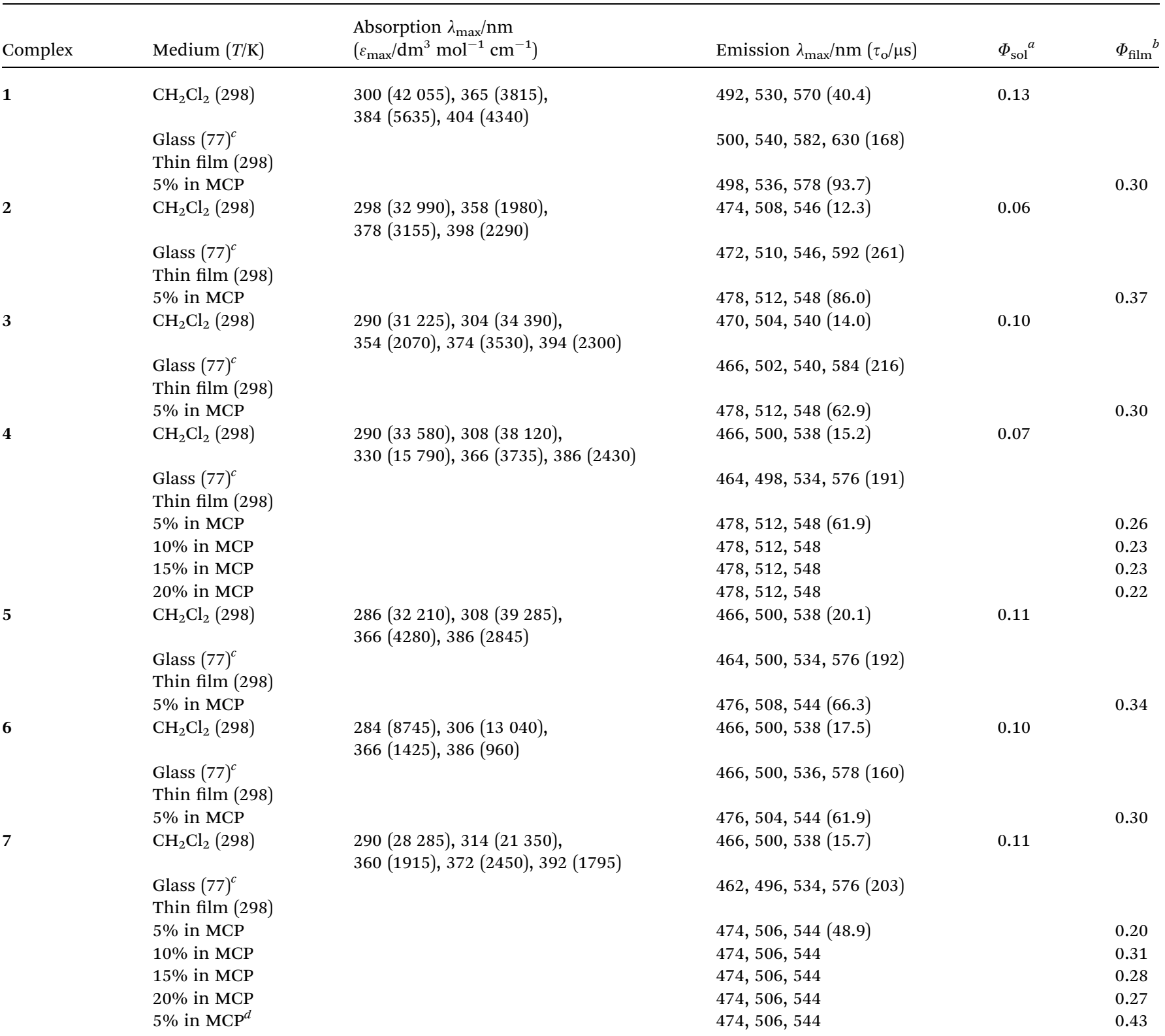

\footnotetext{
${ }^{a}$ The relative luminescence quantum yield in solution was measured at room temperature using quinine sulfate in $0.5 \mathrm{M} \mathrm{H}_{2} \mathrm{SO}_{4}$ as the reference (excitation wavelength $\left.=365 \mathrm{~nm}, \Phi_{\text {lum }}=0.546\right) .{ }^{b} \Phi_{\text {film }}$ of the gold(III) compound doped into MCP thin film and excited at a wavelength of 320 nm. ${ }^{c}$ Measured in EtOH-MeOH- $\mathrm{CH}_{2} \mathrm{Cl}_{2}(40: 10: 1, \mathrm{v} / \mathrm{v}) .{ }^{d}$ Prepared by vacuum deposition.
}

and are depicted in Table 3, in which their highest occupied molecular orbital (HOMO) and lowest unoccupied molecular orbital (LUMO) energy levels are estimated. Selected cyclic voltammograms are shown in Fig. 5. In general, a quasi-reversible reduction couple at $-1.39 \mathrm{~V}$ to $-1.53 \mathrm{~V} v s$. the saturated calomel electrode (SCE) and an irreversible oxidation wave at $+1.75 \mathrm{~V}$ to $+1.89 \mathrm{~V} v s$. SCE are found for 1-7. The first reduction is attributed to the ligand-centered reduction of the cyclometalating ligand. ${ }^{37}$ Notably, the occurrence of the first reduction couple of $2(-1.53 \mathrm{~V}$ vs. SCE $)$ at a more negative value than those of 3 $(-1.50 \mathrm{~V} v s$. SCE) and $5(-1.43 \mathrm{~V} v s$. SCE $)$ is attributed to the positive inductive effect exerted by the tert-butyl group on the phenyl moiety that causes a destabilization of the $\pi^{*}$ orbital. The first oxidation wave of all the complexes has been assigned as the mixing of ligand-centered oxidation of the cyclometalating ligand and the auxiliary aryl ligand. It is found that the oxidation potential is sensitive to the nature of the substituent groups on the phenyl moiety of the $\mathrm{C}^{\wedge} \mathrm{N}^{\wedge} \mathrm{C}$ ligand. The more positive potentials for $6(+1.86 \mathrm{~V} v s$. SCE $)$ and 7 $(+1.89 \mathrm{~V} v s$. SCE $)$ than that for $\mathbf{1}(+1.80 \mathrm{~V} v s$. SCE $)$ are attributed to the more negative inductive effect of the trifluoromethyl and trifluoromethoxy groups exerted on the phenyl moiety that causes a stabilization of the filled $\pi$ orbital. This assignment can be further rationalized by the computational studies in the 


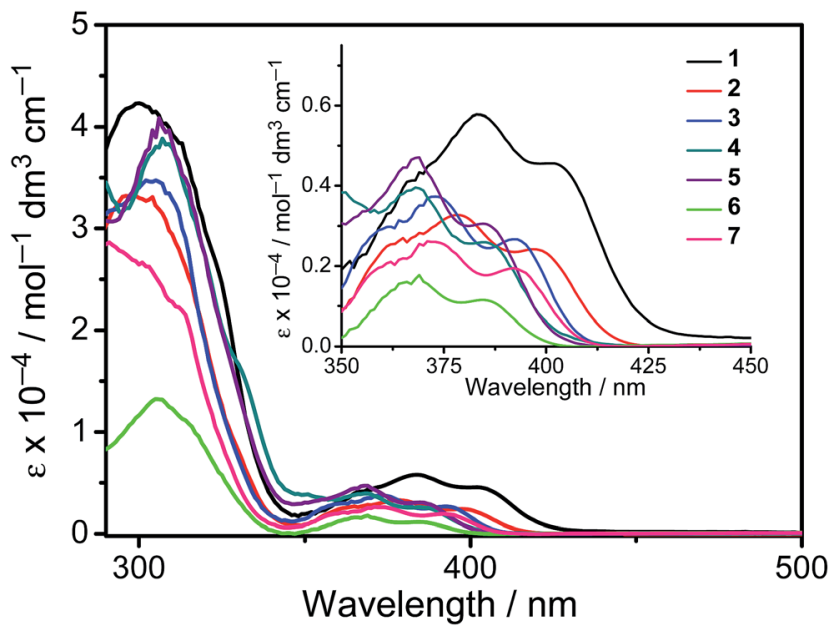

Fig. 2 UV-Vis absorption spectra of 1-7 in dichloromethane solution at $298 \mathrm{~K}$.
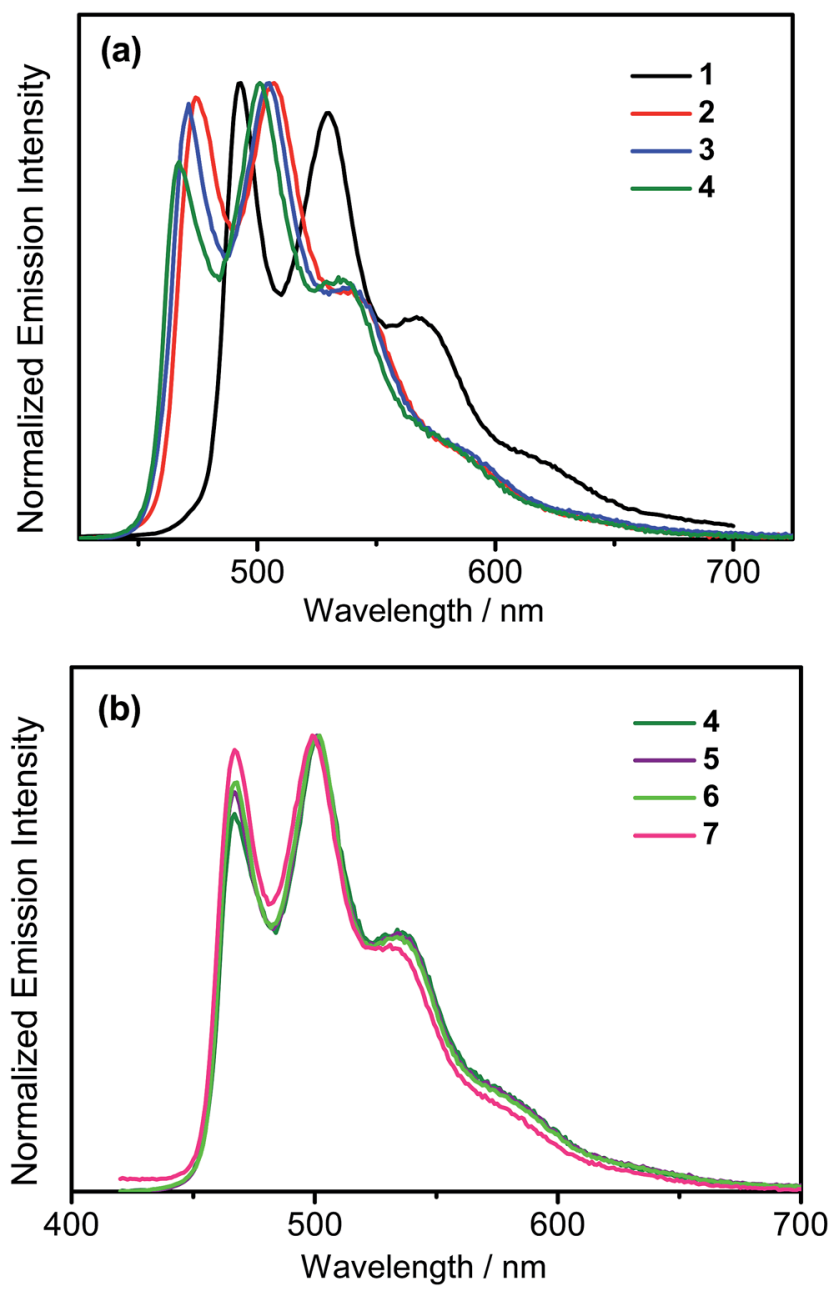

Fig. 3 (a) Normalized emission spectra of (a) 1-4 and (b) 4-7 in dichloromethane solution at $298 \mathrm{~K}$.

structurally related cyclometalated arylgold(III) system reported by our group recently. ${ }^{35}$ In the computational studies, the energy difference between the HOMO and HOMO-1 for this

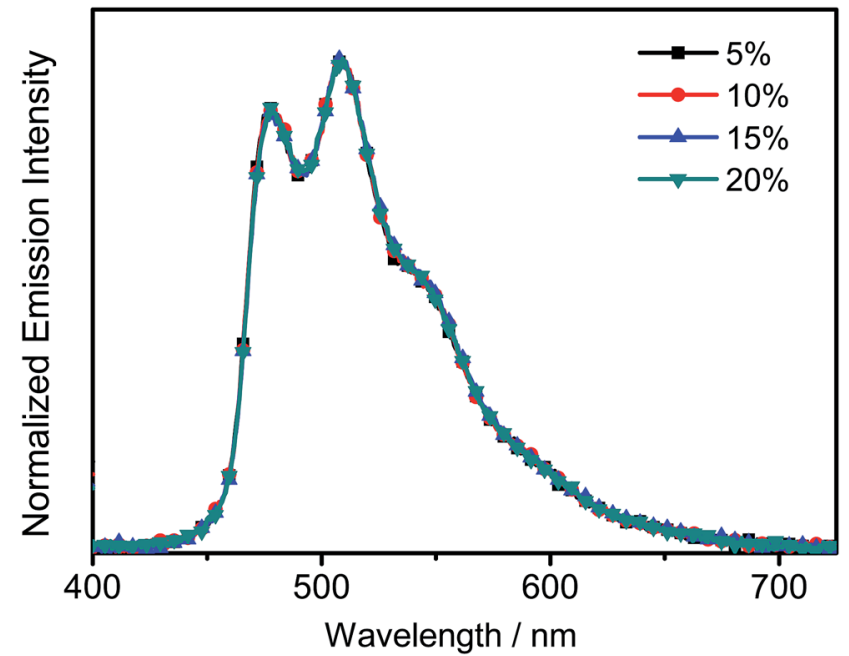

Fig. 4 Normalized PL spectra of thin films of 4 doped into MCP at different concentrations (wt\%) at $298 \mathrm{~K}$.

system is found to be $c a$. $0.15 \mathrm{eV}$, indicating that these two orbitals are close-lying in energy. Moreover, the HOMO-1 is predominantly from the $\pi$ orbital of the $\mathrm{C}^{\wedge} \mathrm{N}^{\wedge} \mathrm{C}$ ligand mixed with a metal $\mathrm{d} \pi$ orbital, and their HOMO is predominantly from the $\pi$ orbital of the auxiliary ligand mixed with a metal $\mathrm{d} \pi$ orbital. This further confirms that the first oxidation waves of these complexes can be fine-tuned by the choice of substituent groups.

\section{OLED device fabrication and characterization}

Compared to our previously reported alkynylgold(III) complexes, this new class of arylgold(III) complexes is both solutionprocessable and thermally evaporable, offering greater flexibility for the fabrication of OLEDs. To test the applicability, solutionprocessable OLEDs with the configuration of indium tin oxide (ITO)/poly(ethylenedioxythiophene):poly(styrene sulfonic acid) (PEDOT:PSS; $70 \mathrm{~nm}$ )/ $x \%$ gold(III) complex:MCP $(60 \mathrm{~nm}) / \operatorname{tris}(2,4,6-$ trimethyl-3-(pyridin-3-yl)phenyl)borane (3ТРYMB; $5 \mathrm{~nm}$ )/1,3,5-tri [(3-pyridyl)phen-3-yl]benzene (TmPyPB; $30 \mathrm{~nm}) / \mathrm{LiF}(0.8 \mathrm{~nm}) / \mathrm{Al}$ $(100 \mathrm{~nm})$ have been prepared, in which the most bluish complexes $\mathbf{4}$ and 7 were used as phosphorescent dopants. Fig. 6 depicts the normalized EL spectra of solution-processable devices doped with $\mathbf{4}$ and $\mathbf{7}$ at different concentrations. All devices exhibit vibronic-structured emission and are independent of the dopant concentration, in agreement with the emission studies. The slight differences between the emission profile of the EL spectrum of $\mathbf{4}$ in solution-processable OLEDs and the PL spectrum of 4 measured in the doped film may be due to the different packing of the molecules that can perturb or modulate the extent of excited state distortion and hence the Huang-Rhys factor. Particularly, both $x$ and $y$ coordinates of all the devices remain unchanged with increasing dopant concentration from $5 \mathrm{wt} \%$ to $20 \mathrm{wt} \%$, i.e. $(0.20,0.41)$ for 4 and $(0.19,0.40)$ for 7 for all of the different dopant concentrations in the range of 5 to $20 \mathrm{wt} \%$. A similar phenomenon is also observed for the vacuumdeposited OLEDs with the structure of ITO/molybdenum 
Table 3 Electrochemical data for $1-7^{a}$

\begin{tabular}{|c|c|c|c|c|}
\hline Complex & Oxidation $\left[E_{\mathrm{pa}} / \mathrm{V} v s . \mathrm{SCE}\right]^{b}$ & $\begin{array}{l}\text { Reduction } E_{1 / 2} / \mathrm{V} v s . \mathrm{SCE}^{c} \\
\left(\Delta E_{\mathrm{p}} / \mathrm{mV}\right)^{d}\left[E_{\mathrm{pc}} / \mathrm{V} v s . \mathrm{SCE}\right]^{e}\end{array}$ & $E_{\text {Номо }}^{f} / \mathrm{eV}$ & $E_{\text {LUMO }} f / \mathrm{eV}$ \\
\hline 1 & {$[+1.80]$} & $-1.44(60),[-1.93]$ & -6.60 & -3.36 \\
\hline 3 & {$[+1.81],[+1.89]$} & $-1.50(63)$ & -6.61 & -3.30 \\
\hline 4 & {$[+1.78],[+1.92]$} & $-1.44(53),[-1.97]$ & -6.58 & -3.36 \\
\hline 5 & {$[+1.81]$} & $-1.43(62),[-1.92]$ & -6.61 & -3.37 \\
\hline
\end{tabular}

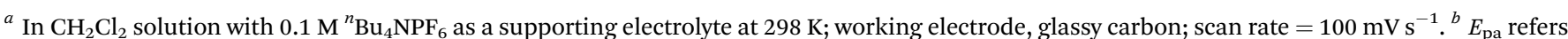
to the anodic peak potential for the irreversible oxidation wave. ${ }^{c} E_{1 / 2}=\left(E_{\mathrm{pa}}+E_{\mathrm{pc}}\right) / 2 ; E_{\mathrm{pa}}$ and $E_{\mathrm{pc}}$ are the peak anodic and peak cathodic potentials, respectively. ${ }^{d} \Delta E_{\mathrm{p}}=\left(E_{\mathrm{pa}}-E_{\mathrm{pc}}\right) .{ }^{e} E_{\mathrm{pc}}$ refers to the cathodic peak potential for the irreversible reduction wave. ${ }^{f} E_{\mathrm{HOMO}}$ and $E_{\mathrm{LUMO}}$ levels were calculated from electrochemical potentials, i.e. $E_{\mathrm{HOMO}}=-\mathrm{e}\left(4.8 \mathrm{~V}+E_{\mathrm{pa}}\right) ; E_{\mathrm{LUMO}}=-\mathrm{e}\left(4.8 \mathrm{~V}+E_{\mathrm{pc}}\right)$.

oxide $\quad\left(\mathrm{MoO}_{x} ; 2 \mathrm{~nm}\right) / \mathrm{di}-[4-(N, N$-di- $p$-tolyl-amino)-phenyl $]$ cyclohexane (TAPC; $40 \mathrm{~nm}) / x \% 4$ or 7:MCP $(25 \mathrm{~nm}) /$ diphenyl4-triphenylsilylphenyl-phosphine oxide (TSPO1; $5 \mathrm{~nm}$ )/1,3,5tris(6-(3-pyridin-3-yl)phenyl)pyridin-2-yl)benzene (Tm3PyP26PyB; $35 \mathrm{~nm}) / \mathrm{LiF}(1 \mathrm{~nm}) / \mathrm{Al}(100 \mathrm{~nm})$, in which no undesired
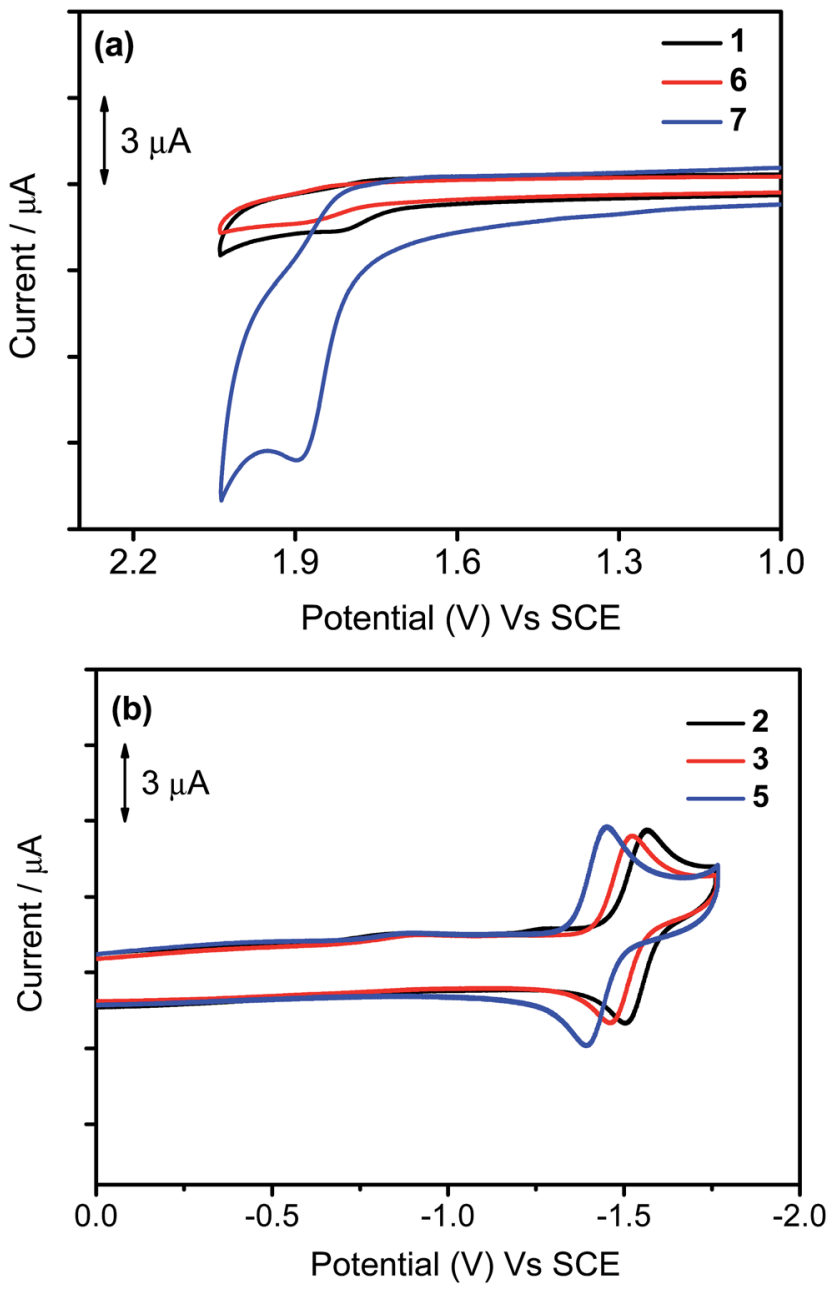

Fig. 5 Cyclic voltammograms for the (a) oxidation of 1, 6, and 7 and (b) reduction scans of 2,3 , and 5 in dichloromethane $\left(0.1 \mathrm{M}^{n} \mathrm{Bu}_{4} \mathrm{NPF}_{6}\right)$. emission from the adjacent carrier-transporting and/or host materials is observed (Fig. 7). This concentration independence is seldom observed for square-planar metal complexes, in which the $\pi$-stacking of the molecules usually leads to the formation of excimeric emission, generating a significant spectral shift and hence poor color purity of the OLEDs. It should be highlighted that the present results open up another effective means to realize sky-blue emission of gold(III) complexes. Unlike the alkynylgold(III) analogues, the steric repulsion between the aryl ring and the $\mathrm{C}^{\wedge} \mathrm{N}^{\wedge} \mathrm{C}$ ligand can effectively suppress the intermolecular interactions. By

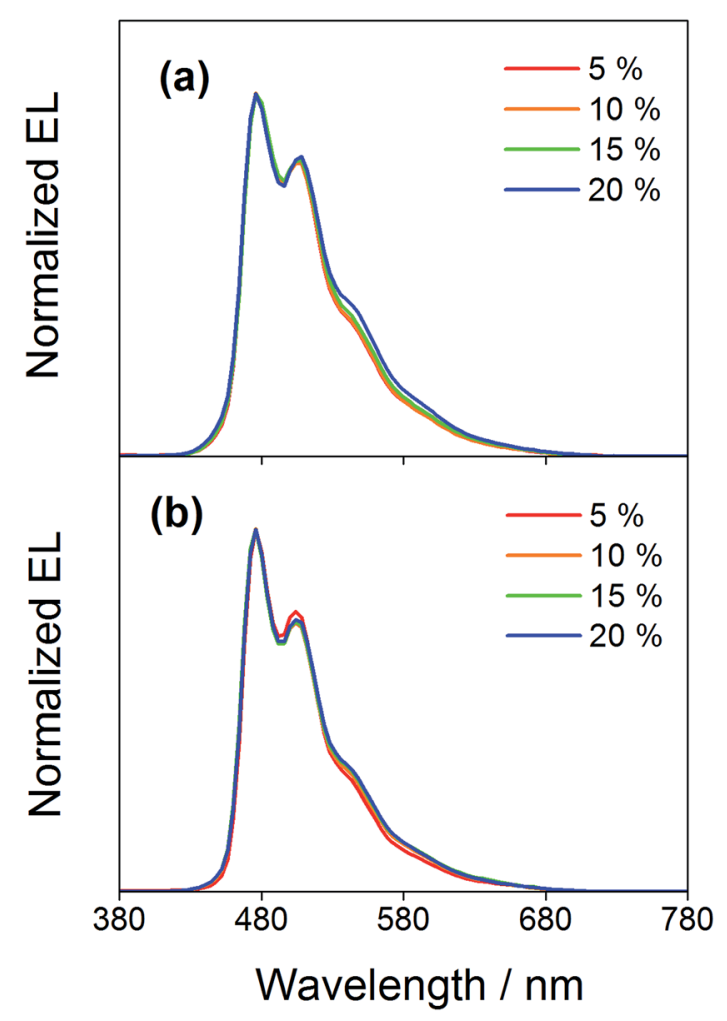

Fig. 6 Normalized EL spectra of solution-processable devices doped with 4 and 7 at different concentrations. 


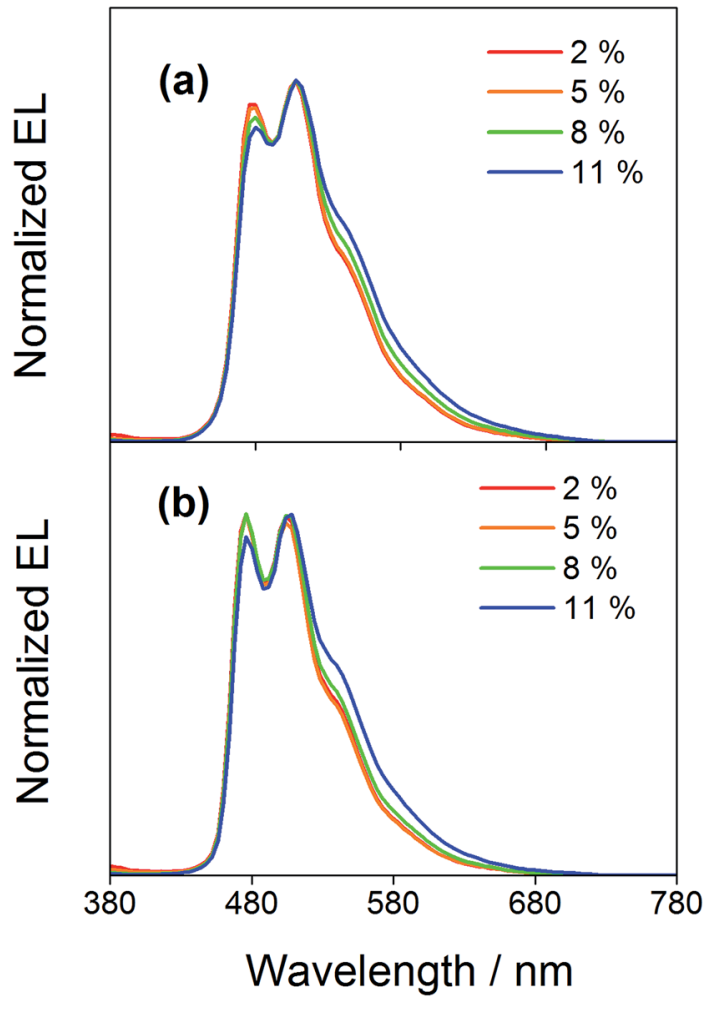

Fig. 7 Normalized EL spectra of vacuum-deposited OLEDs based on 4 and 7. modifying the substituents on the phenyl ring of the $\mathrm{C}^{\wedge} \mathrm{N}^{\wedge} \mathrm{C}$ ligand, ready fine-tuning of the energy of the arylgold(III) complexes into the blue region has been realized.

In addition to high color purity, satisfactory device performance has been obtained for both solution-processable and vacuum-deposited OLEDs. For solution-processable devices, the optimized devices doped with $\mathbf{4}$ and $\mathbf{7}$ show maximum EQEs of $2.3 \%$ and $5.3 \%$, respectively. While both gold(III) complexes have similar PLQYs, the discrepancy in the EQEs may be due to the better solubility of 7 , yielding more uniform thin films. This solubility problem can be diminished by using thermal evaporation, in which both devices exhibit comparable EQEs of up to $10.7 \%$ and $11.3 \%$, respectively (Tables 4 and 5). Fig. 8 and 9 depict the EQEs of solution-processable and vacuum-deposited devices made with 4 and 7 , respectively. The operational stability of the vacuum-deposited device based on $5 \mathrm{wt} \%$ complex 7 has been investigated and tested at a constant driving current density of $20 \mathrm{~mA} \mathrm{~cm}{ }^{-2}$. An operational half-life of $\sim 48$ hours at a luminance of $100 \mathrm{~cd}$ $\mathrm{m}^{-2}$ is estimated according to the accelerated lifetime testing method (Fig. 10). These findings clearly demonstrate that this new class of sky-blue-emitting arylgold(III) complexes shows promise as phosphorescent dopants for both high performance solution-processable and vacuum-deposited OLEDs. More importantly, this work represents the first successful demonstration of blue-emitting gold(III) complexes with CIE $x$ coordinate $<0.2$.

Table 4 Key parameters of solution-processable devices based on 4 and 7

\begin{tabular}{|c|c|c|c|c|c|}
\hline \multirow[t]{3}{*}{4} & 5 & 1.8 & 0.5 & 0.7 & $476(0.20,0.41)$ \\
\hline & 15 & 5.6 & 2.4 & 2.3 & $476(0.20,0.41)$ \\
\hline & 20 & 3.7 & 1.4 & 1.5 & $476(0.21,0.41)$ \\
\hline \multirow[t]{2}{*}{7} & 5 & 5.8 & 2.1 & 2.5 & $476(0.19,0.40)$ \\
\hline & 20 & 12.6 & 7.9 & 5.3 & $476(0.19,0.40)$ \\
\hline
\end{tabular}

${ }^{a} \mathrm{CIE}$ coordinates in parentheses, measured at $100 \mathrm{~cd} \mathrm{~m}^{-2}$.

Table 5 Key parameters of vacuum-deposited devices based on 4 and 7

\begin{tabular}{|c|c|c|c|c|c|}
\hline \multirow[t]{3}{*}{4} & 2 & 12.5 & 9.8 & 4.8 & $508(0.20,0.45)$ \\
\hline & 8 & 30.1 & 31.6 & 10.7 & $508(0.22,0.47)$ \\
\hline & 11 & 24.5 & 25.7 & 8.5 & $508(0.23,0.48)$ \\
\hline \multirow[t]{2}{*}{7} & 2 & 13.8 & 12.4 & 6.0 & $476(0.19,0.43)$ \\
\hline & 11 & 35.2 & 31.6 & 11.2 & $508(0.22,0.47)$ \\
\hline
\end{tabular}

${ }^{a} \mathrm{CIE}$ coordinates in parentheses, measured at $100 \mathrm{~cd} \mathrm{~m}^{-2}$. 


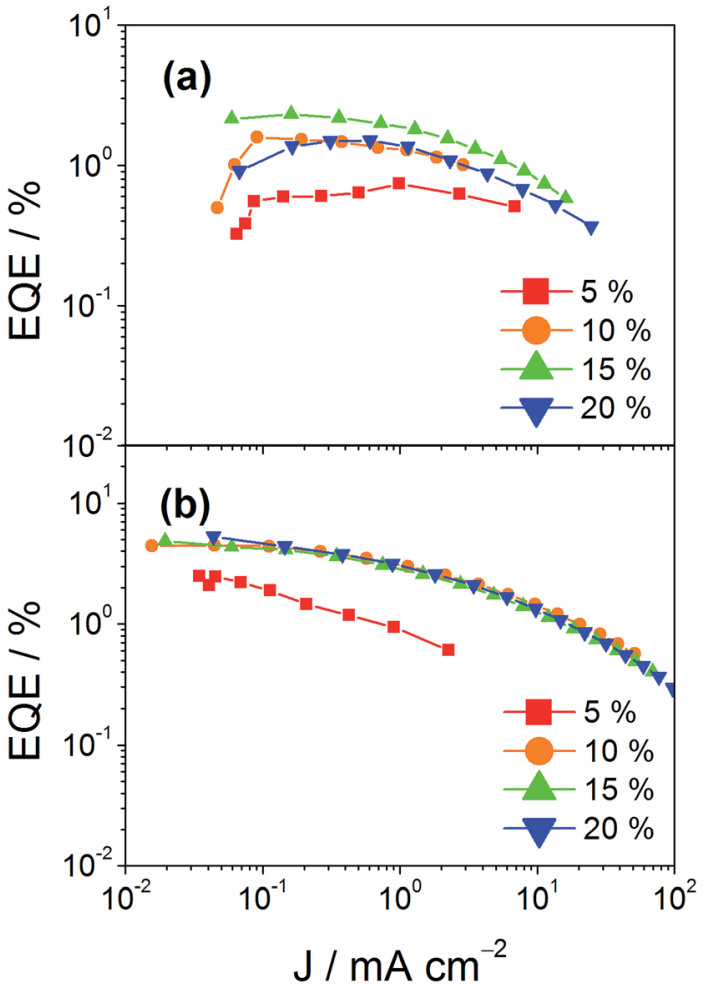

Fig. 8 EQEs of solution-processable devices made with (a) 4 and (b) 7 at different concentrations.

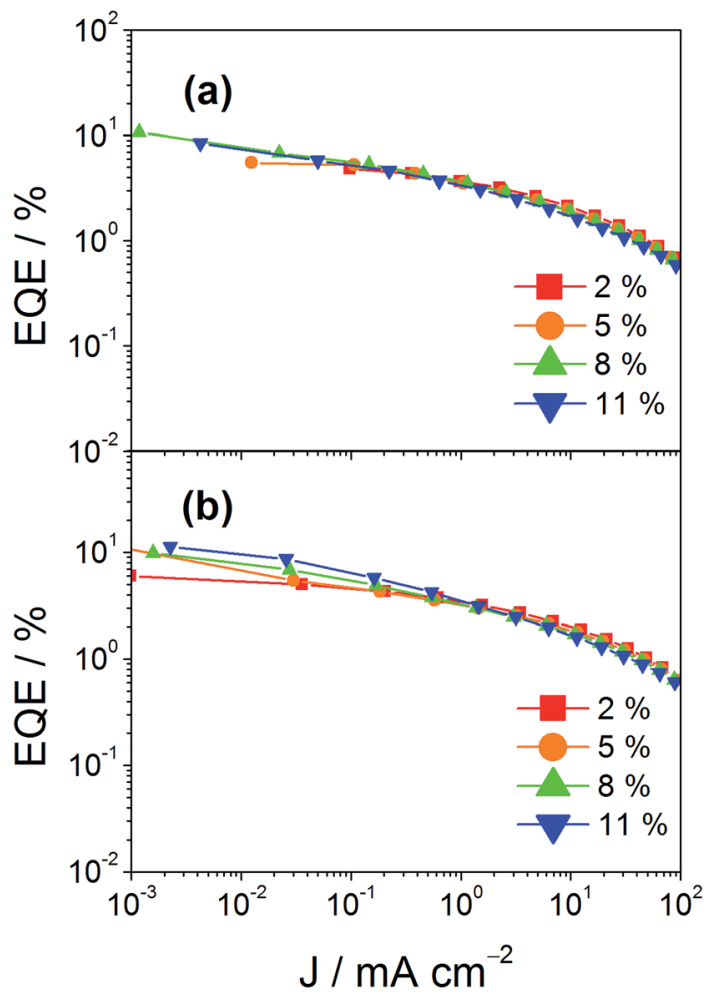

Fig. 9 EQEs of vacuum-deposited devices made with (a) 4 and (b) 7 at different concentrations.

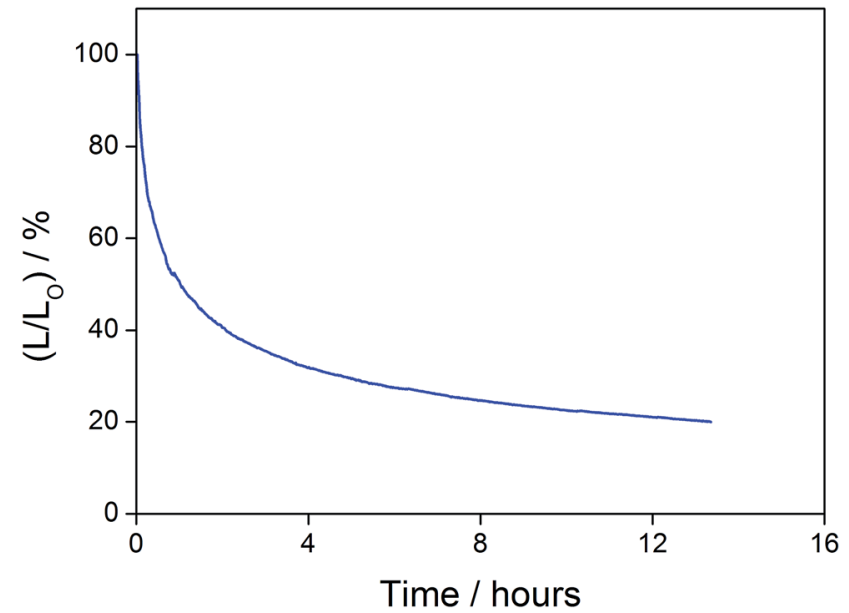

Fig. 10 Relative luminance of vacuum-deposited OLEDs based on $5 \mathrm{wt} \%$ complex 7 as a function of operation time at a constant driving current density of $20 \mathrm{~mA} \mathrm{~cm}{ }^{-2}$.

\section{Conclusion}

A new class of sky-blue-emitting arylgold(III) complexes of 2,6diphenylpyridine has been designed and synthesized by engineering the substituents on the phenyl ring, in which the emission energies have been effectively fine-tuned from $492 \mathrm{~nm}$ to $466 \mathrm{~nm}$ in dichloromethane solution. It is found that the incorporation of more fluorine atoms would cause a higher excited state distortion with respect to the ground state, while trifluoromethylation is an effective way to shift the emission to the blue region. More importantly, this class of arylgold(III) complexes is capable of serving as phosphorescent dopants with high EQEs of up to $5.3 \%$ and $11.3 \%$ for both solutionprocessable and vacuum-deposited OLEDs, respectively, opening up a versatile approach to realize blue emission in square-planar gold(III) complexes.

\section{Experimental section}

\section{Materials}

The tridentate ligands, $4-\mathrm{CN}-\mathrm{C}^{\wedge} \mathrm{N}\left(4-{ }^{t} \mathrm{BuC}_{6} \mathrm{H}_{4}\right) \wedge \mathrm{C}^{t} \mathrm{Bu}-4,3,5-\mathrm{F}_{2}-$ $\mathrm{C}^{\wedge} \mathrm{N}\left(4-{ }^{t} \mathrm{BuC}_{6} \mathrm{H}_{4}\right) \wedge \mathrm{C}^{t} \mathrm{Bu}-4, \quad 3,5-\mathrm{F}_{2}-\mathrm{C}^{\wedge} \mathrm{N}\left(4-{ }^{t} \mathrm{BuC}_{6} \mathrm{H}_{4}\right)^{\wedge} \mathrm{C}-\mathrm{F}-4, \quad 3,5-\mathrm{F}_{2}-$ $\mathrm{C}^{\wedge} \mathrm{N}\left(4-{ }^{t} \mathrm{BuC}_{6} \mathrm{H}_{4}\right){ }^{\wedge} \mathrm{C}-\mathrm{F}_{2}-3,5, \quad 3,5-\mathrm{F}_{2}-\mathrm{C}^{\wedge} \mathrm{N}\left(4-{ }^{t} \mathrm{BuC}_{6} \mathrm{H}_{4}\right) \wedge \mathrm{C}^{-} \mathrm{CF}_{3}-4, \quad 4-$ $\mathrm{CF}_{3}-\mathrm{C}^{\wedge} \mathrm{N}\left(4-{ }^{t} \mathrm{BuC}_{6} \mathrm{H}_{4}\right)^{\wedge} \mathrm{C}-\mathrm{CF}_{3}-4$, and $4-\mathrm{OCF}_{3}-\mathrm{C}^{\wedge} \mathrm{N}\left(4-{ }^{t} \mathrm{BuC}_{6} \mathrm{H}_{4}\right){ }^{\wedge} \mathrm{C}-$ $\mathrm{OCF}_{3}-4$, and the precursor gold(III) complexes, [Au $\{4-\mathrm{CN}$ $\left.\left.\mathrm{C}^{\wedge} \mathrm{N}\left(4-{ }^{t} \mathrm{BuC}_{6} \mathrm{H}_{4}\right) \wedge \mathrm{C}^{t} \mathrm{Bu}-4\right\} \mathrm{Cl}\right], \quad\left[\mathrm{Au}\left\{3,5-\mathrm{F}_{2}-\mathrm{C}^{\wedge} \mathrm{N}\left(4-{ }^{t}{ }^{\mathrm{BuC}}{ }_{6} \mathrm{H}_{4}\right)^{\wedge} \mathrm{C}^{t} \mathrm{Bu}-\right.\right.$ 4\}Cl], $\quad\left[\mathrm{Au}\left\{3,5-\mathrm{F}_{2}-\mathrm{C}^{\wedge} \mathrm{N}\left(4-{ }^{t} \mathrm{BuC}_{6} \mathrm{H}_{4}\right)^{\wedge} \mathrm{C}-\mathrm{F}-4\right\} \mathrm{Cl}\right], \quad\left[\mathrm{Au}\left\{3,5-\mathrm{F}_{2}-\right.\right.$ $\left.\left.\mathrm{C}^{\wedge} \mathrm{N}\left(4-{ }^{t} \mathrm{BuC}_{6} \mathrm{H}_{4}\right){ }^{\wedge} \mathrm{C}-\mathrm{F}_{2}-3,5\right\} \mathrm{Cl}\right], \quad\left[\mathrm{Au}\left\{3,5-\mathrm{F}_{2}-\mathrm{C}^{\wedge} \mathrm{N}\left(4-{ }^{t} \mathrm{BuC}_{6} \mathrm{H}_{4}\right)^{\wedge} \mathrm{C}-\right.\right.$ $\left.\left.\mathrm{CF}_{3}-4\right\} \mathrm{Cl}\right], \quad\left[\mathrm{Au}\left\{4-\mathrm{CF}_{3}-\mathrm{C}^{\wedge} \mathrm{N}\left(4-{ }^{t} \mathrm{BuC}_{6} \mathrm{H}_{4}\right)^{\wedge} \mathrm{C}^{-} \mathrm{CF}_{3}-4\right\} \mathrm{Cl}\right]$ and $[\mathrm{Au}\{4-$ $\left.\left.\mathrm{OCF}_{3}-\mathrm{C}^{\wedge} \mathrm{N}\left(4-{ }^{t} \mathrm{BuC}_{6} \mathrm{H}_{4}\right) \wedge \mathrm{C}^{-} \mathrm{OCF}_{3}-4\right\} \mathrm{Cl}\right]$, were prepared via modification of the procedures reported in the literature. ${ }^{42,43}$ Specifically, the $\mathrm{C}^{\wedge} \mathrm{N}^{\wedge} \mathrm{C}$ pincer ligands were refluxed with mercuric(II) acetate in ethanol. Saturated lithium chloride in hot methanol was added to the reaction mixture to yield the mercury precursor complexes as a white precipitate. The mercury precursors were then refluxed with $\mathrm{K}\left[\mathrm{AuCl}_{4}\right]$ in acetonitrile. After removal of solvent, the crude product was purified by 
column chromatography on silica gel to yield the chlorogold(III) precursor complexes as a pale yellow solid. 4-Acetylbenzonitrile, 3,5-difluoroacetophenone, 4-fluoroacetophenone, 4-tert-butylacetophenone, 4-(trifluoromethyl)acetophenone, 4-(trifluoromethoxy) acetophenone and 4-tert-butylphenylboronic acid were purchased from Sigma Aldrich or Matrix Scientific. All solvents were purified and distilled using standard procedures before use. All other reagents were of analytical grade and were used as received. Triethylamine was distilled over calcium hydride before use. Tetra$n$-butylammonium hexafluorophosphate (Aldrich, 98\%) was recrystallized for no less than three times from hot absolute ethanol prior to use. All reactions were performed under anaerobic and anhydrous conditions using standard Schlenk techniques under an inert atmosphere of nitrogen.

\section{Physical measurements and instrumentation}

The UV-vis absorption spectra were recorded on a Cary 60 UV/Vis (Agilent Technology) spectrophotometer equipped with a xenon flash lamp. ${ }^{1} \mathrm{H}$ and ${ }^{13} \mathrm{C}\left\{{ }^{1} \mathrm{H}\right\}$ NMR spectra were recorded on a Bruker Avance $600\left(600 \mathrm{MHz}\right.$ for ${ }^{1} \mathrm{H}$ and $150 \mathrm{MHz}$ for ${ }^{13} \mathrm{C}$ nuclei) Fourier-transform NMR spectrometer with chemical shifts reported relative to tetramethylsilane $(\delta=0 \mathrm{ppm})$ in deuterated chloroform. ${ }^{19} \mathrm{~F}\left\{{ }^{1} \mathrm{H}\right\}$ NMR spectra were recorded on a Bruker Avance 400 (376 MHz for ${ }^{19} \mathrm{~F}$ nucleus) Fouriertransform NMR spectrometer with chemical shifts reported relative to trifluoroacetic acid $(\delta=-76.55 \mathrm{ppm})$ in deuterated chloroform. Positive FAB mass spectra were recorded on a Thermo Scientific DFS High Resolution Magnetic Sector Mass Spectrometer. IR spectra were recorded as $\mathrm{KBr}$ disks on a BioRad FTS-7 FTIR spectrometer (4000-400 $\mathrm{cm}^{-1}$ ). Elemental analyses were performed on a Carlo Erba 1106 elemental analyzer at the Institute of Chemistry, Chinese Academy of Sciences in Beijing. Steady-state excitation and emission spectra were recorded on a Horiba Scientific FluoroMax-4 fluorescence spectrofluorometer equipped with an R928P PMT detector. Liquid nitrogen was placed into a quartz-walled optical Dewar flask for low temperature (77 K) photophysical measurements. Solid-state photophysical measurements were performed with solid samples loaded into a quartz tube inside the quartz-walled Dewar flask. Excited-state lifetimes of solution and glass samples were measured using a conventional laser system. The excitation source used was the $355 \mathrm{~nm}$ output (third harmonic, $8 \mathrm{~ns}$ ) of a Spectra-Physics Quanta-Ray Q-switched GCR-150 pulsed Nd:YAG laser $(10 \mathrm{~Hz})$. Luminescence decay signals were detected with a Hamamatsu R928 photomultiplier tube, recorded on a Tektronix model TDS-620A (500 MHz, $2 \mathrm{GS} \mathrm{s}^{-1}$ ) digital oscilloscope and analyzed with a program for exponential fits. PLQYs were measured by the optical dilute method reported by Demas and Crosby. ${ }^{44}$ An aqueous solution of quinine sulfate in $0.5 \mathrm{M} \mathrm{H}_{2} \mathrm{SO}_{4}$ has been used as the reference $\left(\Phi_{\text {lum }}=0.546\right.$, excitation wavelength of $\left.365 \mathrm{~nm}\right),{ }^{44}$ whereas thin film PLQYs were measured on a Hamamatsu C9920-03 Absolute PLQY Measurement System. Excited-state lifetimes of thin films were measured on a Hamamatsu C11367-34 Quantaurus-Tau Fluorescence lifetime spectrometer. Cyclic voltammetry was performed with a $\mathrm{CH}$ Instruments Model CHI620E $(\mathrm{CH}$
Instruments, Inc.). All solutions for electrochemical measurements were purged with pre-purified argon gas prior to measurement. Thermal analyses were performed with a Q50 TGA (TA instruments), in which the decomposition temperature, $T_{\mathrm{d}}$, is defined as the temperature at which the sample shows a $5 \%$ weight loss.

\section{OLED fabrication and characterization}

Solution-processable OLEDs were fabricated on patterned ITO glass substrates with a sheet resistance of $30 \Omega$ per square. The substrates were cleaned with Decon 90, rinsed with deionized water, dried in an oven, and finally treated in an ultravioletozone chamber. A $70 \mathrm{~nm}$ thick PEDOT:PSS layer was spin-coated onto the ITO coated glass substrates as a hole-transporting layer. After that, the emissive layer was formed by mixing the gold(III) complex with MCP to prepare a $10 \mathrm{mg} \mathrm{cm}^{-3}$ solution in chloroform and spin-coating it onto the PEDOT:PSS layer to give uniform thin films of $60 \mathrm{~nm}$ thickness. Onto this, $5 \mathrm{~nm}$ thick 3TPYMB and a $30 \mathrm{~nm}$ thick TMPyPB were evaporated as a holeblocking layer and an electron-transporting layer, respectively, while $\mathrm{LiF} / \mathrm{Al}$ was used as the metal cathode. For vacuumdeposited OLEDs, sequential thermal evaporation of $\mathrm{MoO}_{x}$, TAPC, the emissive layer, TSPO1, Tm3P26PyB, LiF and Al was done onto the ITO substrates. All organic and metal films were sequentially deposited at a rate of $0.1-0.2 \mathrm{~nm} \mathrm{~s}^{-1}$ without any vacuum break. A shadow mask was used to define the cathode and to make four $0.1 \mathrm{~cm}^{2}$ devices on each substrate. Current density-voltage-luminance characteristics and EL spectra were measured simultaneously with a programmable Keithley model 2420 power source and a Photoresearch PR-655 spectrometer. The operational stability of OLEDs was tested under accelerated lifetime testing conditions and the half-life was estimated using the equation $t_{1 / 2}=$ constant $/\left(L_{0}\right)^{n}$, where $L_{0}$ is the initial luminance, $t_{1 / 2}$ is the measured half-life, and $m$ is an acceleration factor taken to be 1.7 .

\section{Synthesis and characterization of gold(III) complexes}

Complexes 1-7 were synthesized by reacting the respective chlorogold(III) precursors with 4-tert-butylphenylboronic acid in the presence of a catalytic amount of palladium(II) catalyst in an aqueous base and organic solvent. For instance, to a two-necked flask containing [ $\left.\mathrm{Au}\left\{4-\mathrm{CN}-\mathrm{C}^{\wedge} \mathrm{N}\left(4{ }^{-}{ }^{t} \mathrm{BuC}_{6} \mathrm{H}_{4}\right)^{\wedge} \mathrm{C}^{t} \mathrm{Bu}-4\right\} \mathrm{Cl}\right](0.14 \mathrm{~g}$, $0.23 \mathrm{mmol}$ ), $\mathrm{K}_{2} \mathrm{CO}_{3}\left(0.55 \mathrm{~g}, 0.43 \mathrm{mmol}\right.$ ), $\mathrm{Pd}(\mathrm{OAc})_{2}$ (7.20 mg, 0.023 $\mathrm{mmol}),\left[\mathrm{HP}\left({ }^{t} \mathrm{Bu}\right)_{3}\right] \mathrm{BF}_{4}(13.30 \mathrm{mg}, 0.046 \mathrm{mmol})$ and 4-tert-butylphenylboronic acid $(0.82 \mathrm{~g}, 0.46 \mathrm{mmol})$ were added into degassed toluene and $\mathrm{H}_{2} \mathrm{O}(4: 1, \mathrm{v} / \mathrm{v})$ and the mixture was stirred at $80{ }^{\circ} \mathrm{C}$ for 12 hours under a nitrogen atmosphere. After removing the solvent, the crude product was purified by column chromatography on silica gel (70-230 mesh) using hexane-dichloromethane $(6: 1, v / v)$ as the eluent. Subsequent recrystallization by diffusion of diethyl ether vapor into a concentrated dichloromethane solution gave the product as a pale yellow solid.

Complex 1. Yield: $53.6 \mathrm{mg}, 34 \% .{ }^{1} \mathrm{H}$ NMR $\left(500 \mathrm{MHz}, \mathrm{THF}_{8}\right.$, $298 \mathrm{~K}, \delta / \mathrm{ppm}): \delta 8.09\left(\mathrm{~d}, J=1.5 \mathrm{~Hz}, 1 \mathrm{H},-\right.$ py of $\left.\mathrm{C}^{\wedge} \mathrm{N}^{\wedge} \mathrm{C}\right), 8.05-8.03$ $\left(\mathrm{m}, 2 \mathrm{H},-\right.$ py and $-\mathrm{C}_{6} \mathrm{H}_{3}{ }^{t} \mathrm{Bu}-$ of $\left.\mathrm{C}^{\wedge} \mathrm{N}^{\wedge} \mathrm{C}\right), 7.87(\mathrm{~d}, J=8.5 \mathrm{~Hz}, 2 \mathrm{H}$, $-\mathrm{C}_{6} \mathrm{H}_{4}-$ of $\left.\mathrm{C}^{\wedge} \mathrm{N}^{\wedge} \mathrm{C}\right), 7.79\left(\mathrm{~d}, J=8.0 \mathrm{~Hz}, 1 \mathrm{H},-\mathrm{C}_{6} \mathrm{H}_{3} \mathrm{CN}-\right.$ of $\left.\mathrm{C}^{\wedge} \mathrm{N}^{\wedge} \mathrm{C}\right)$, 
$7.65\left(\mathrm{~d}, 1 \mathrm{H}, J=2.0 \mathrm{~Hz},-\mathrm{C}_{6} \mathrm{H}_{3} \mathrm{CN}-\right.$ of $\left.\mathrm{C}^{\wedge} \mathrm{N}^{\wedge} \mathrm{C}\right), 7.62(\mathrm{~d}, J=8.5 \mathrm{~Hz}$, $2 \mathrm{H},-\mathrm{C}_{6} \mathrm{H}_{4}-$ of $\left.\mathrm{C}^{\wedge} \mathrm{N}^{\wedge} \mathrm{C}\right), 7.56(\mathrm{dd}, J=8.0$ and $2.0 \mathrm{~Hz}, 1 \mathrm{H}$, $-\mathrm{C}_{6} \mathrm{H}_{3} \mathrm{CN}-$ of $\left.\mathrm{C}^{\wedge} \mathrm{N}^{\wedge} \mathrm{C}\right), 7.52\left(\mathrm{~d}, J=8.5 \mathrm{~Hz}, 2 \mathrm{H},-\mathrm{C}_{6} \mathrm{H}_{4}{ }^{t} \mathrm{Bu}-p\right), 7.41$ $\left(\mathrm{d}, J=2.0 \mathrm{~Hz}, 1 \mathrm{H},-\mathrm{C}_{6} \mathrm{H}_{3}{ }^{t} \mathrm{Bu}-\right.$ of $\left.\mathrm{C}^{\wedge} \mathrm{N}^{\wedge} \mathrm{C}\right), 7.36(\mathrm{~d}, J=8.5 \mathrm{~Hz}, 2 \mathrm{H}$, $-\mathrm{C}_{6} \mathrm{H}_{4}{ }^{t} \mathrm{Bu}-p$ ), 7.27 (dd, $J=8.5$ and $2.0 \mathrm{~Hz}, 1 \mathrm{H},-\mathrm{C}_{6} \mathrm{H}_{3}{ }^{t} \mathrm{Bu}-$ of $\left.\mathrm{C}^{\wedge} \mathrm{N}^{\wedge} \mathrm{C}\right), 1.40\left(\mathrm{~s}, 9 \mathrm{H},{ }^{t} \mathrm{Bu},-\mathrm{C}_{6} \mathrm{H}_{4}-\right.$ of $\left.\mathrm{C}^{\wedge} \mathrm{N}^{\wedge} \mathrm{C}\right), 1.39\left(\mathrm{~s}, 9 \mathrm{H},{ }^{t} \mathrm{Bu}\right.$, ${ }_{-} \mathrm{C}_{6} \mathrm{H}_{4}{ }^{t} \mathrm{Bu}-p$ ), 1.23 (s, 9H, ${ }^{t} \mathrm{Bu},-\mathrm{C}_{6} \mathrm{H}_{3}{ }^{t} \mathrm{Bu}-$ of $\mathrm{C}^{\wedge} \mathrm{N}^{\wedge} \mathrm{C}$ ). $\left.{ }^{13} \mathrm{C}^{1}{ }^{1} \mathrm{H}\right\}$ $\mathrm{NMR}\left(150 \mathrm{MHz}, \mathrm{CDCl}_{3}, \delta / \mathrm{ppm}\right): \delta 169.78,166.25,163.57,161.07$, 154.88 , 154.77, 154.05, 153.82, 147.66, 146.61, 143.14, 138.82, $134.64,133.33,132.65,130.02,127.07,126.40,125.96,124.98$, $124.36,123.60,119.73,115.62,115.24,113.75,35.35,34.92$, 34.40, 31.52, 31.25, 31.06. Positive ESI-MS: $m / z 773.3[\mathrm{M}+\mathrm{H}]^{+}$. Elemental analyses: found (\%): C 64.98, H 5.51, N 3.60. Calcd for $\mathrm{AuC}_{42} \mathrm{H}_{43} \mathrm{~N}_{2}$ : C 65.28, H 5.61, N 3.63.

Complex 2. Yield: $50 \mathrm{mg}, 44 \% .{ }^{1} \mathrm{H}$ NMR $\left(500 \mathrm{MHz}, \mathrm{CDCl}_{3}\right.$, $298 \mathrm{~K}$, relative to $\left.\mathrm{Me}_{4} \mathrm{Si}, \delta / \mathrm{ppm}\right): \delta 7.67-7.65(\mathrm{~m}, 3 \mathrm{H},-$ py and $-\mathrm{C}_{6} \mathrm{H}_{4}-$ of $\left.\mathrm{C}^{\wedge} \mathrm{N}^{\wedge} \mathrm{C}\right), 7.62\left(\mathrm{~s}, 1 \mathrm{H},-\right.$ py of $\left.\mathrm{C}^{\wedge} \mathrm{N}^{\wedge} \mathrm{C}\right), 7.59-7.56(\mathrm{~m}, 3 \mathrm{H}$, $-\mathrm{C}_{6} \mathrm{H}_{4}-$ and $-\mathrm{C}_{6} \mathrm{H}_{3}{ }^{t} \mathrm{Bu}-$ of $\left.\mathrm{C}^{\wedge} \mathrm{N}^{\wedge} \mathrm{C}\right), 7.55-7.53(\mathrm{~d}, J=8.0 \mathrm{~Hz}, 2 \mathrm{H}$, $\left.-\mathrm{C}_{6} \mathrm{H}_{4}{ }^{t} \mathrm{Bu}-p\right)$, 7.29-7.23 (m, $4 \mathrm{H},-\mathrm{C}_{6} \mathrm{H}_{3}{ }^{t} \mathrm{Bu}-$ of $\mathrm{C}^{\wedge} \mathrm{N}^{\wedge} \mathrm{C}$ and $-\mathrm{C}_{6} \mathrm{H}_{4}{ }^{t} \mathrm{Bu}-p$ ), 7.07-7.06 (m, $1 \mathrm{H},-\mathrm{F}_{2} \mathrm{C}_{6} \mathrm{H}_{2}-$ of $\left.\mathrm{C}^{\wedge} \mathrm{N}^{\wedge} \mathrm{C}\right), 6.73-6.70$ $\left(\mathrm{m}, 1 \mathrm{H},-\mathrm{F}_{2} \mathrm{C}_{6} \mathrm{H}_{2}-\right.$ of $\left.\mathrm{C}^{\wedge} \mathrm{N}^{\wedge} \mathrm{C}\right), 1.40\left(\mathrm{~s}, 9 \mathrm{H},{ }^{t} \mathrm{Bu},-\mathrm{C}_{6} \mathrm{H}_{4}-\right.$ of $\left.\mathrm{C}^{\wedge} \mathrm{N}^{\wedge} \mathrm{C}\right), 1.38\left(\mathrm{~s}, 9 \mathrm{H},-{ }^{t} \mathrm{Bu},-{ }_{-}{ }_{6} \mathrm{H}_{4}{ }^{t} \mathrm{Bu}-p\right), 1.17\left(\mathrm{~s}, 9 \mathrm{H},{ }^{t} \mathrm{Bu}\right.$, ${ }_{-\mathrm{C}_{6}} \mathrm{H}_{3}{ }^{t} \mathrm{Bu}-$ of $\left.\mathrm{C}^{\wedge} \mathrm{N}^{\wedge} \mathrm{C}\right) .{ }^{13} \mathrm{C}\left\{{ }^{1} \mathrm{H}\right\} \mathrm{NMR}\left(150 \mathrm{MHz}, \mathrm{CDCl}_{3}, \delta / \mathrm{ppm}\right)$ : $\delta$ 168.07, 167.99, 166.47, 166.39, 163.98, 163.96, 163.17, 163.08, $163.00,161.63,161.61,161.46,161.38,154.83,154.62,153.95$, $152.15,152.09,152.02,151.97,148.30,148.28,148.00,147.98$, 146.82, 146.10, 140.34, 140.32, 134.71, 133.11, 132.09, 127.06, 126.37, 125.10, 124.69, 123.59, 115.14, 114.85, 108.70, 108.68, $108.55,108.53,106.37,106.21,106.14,35.21,34.91,34.25$, 31.52, 31.25, 30.90. ${ }^{19} \mathrm{~F}\left\{{ }^{1} \mathrm{H}\right\}$ NMR (470 MHz, $\mathrm{CDCl}_{3}$, relative to $\left.\mathrm{CF}_{3} \mathrm{COOH}, \delta / \mathrm{ppm}\right): \delta-85.70,-113.23$. Positive ESI-MS: $\mathrm{m} / \mathrm{z}$ $784.3[\mathrm{M}+\mathrm{H}]^{+}$. Elemental analyses: found (\%): $\mathrm{C} 62.54, \mathrm{H}$ 5.37, N 1.74. Calcd for $\mathrm{AuC}_{41} \mathrm{H}_{42} \mathrm{NF}_{2}$ : C 62.83, H 5.40, N 1.79.

Complex 3. Yield: $200 \mathrm{mg}, 58 \% .{ }^{1} \mathrm{H}$ NMR $\left(500 \mathrm{MHz}, \mathrm{CD}_{2} \mathrm{Cl}_{2}\right.$, $298 \mathrm{~K}, \delta / \mathrm{ppm}): \delta 7.76-7.68\left(\mathrm{~m}, 5 \mathrm{H},-\mathrm{F}_{2} \mathrm{C}_{6} \mathrm{H}_{2}-\right.$ and - py of $\mathrm{C}^{\wedge} \mathrm{N}^{\wedge} \mathrm{C}$, and $\left.-\mathrm{C}_{6} \mathrm{H}_{4}{ }^{t} \mathrm{Bu}-p\right), 7.61\left(\mathrm{~d}, J=8.5 \mathrm{~Hz}, 2 \mathrm{H},-\mathrm{C}_{6} \mathrm{H}_{4}{ }^{t} \mathrm{Bu}-p\right), 7.45(\mathrm{~d}, J$ $=8.0 \mathrm{~Hz}, 2 \mathrm{H},-\mathrm{C}_{6} \mathrm{H}_{4}-$ of $\left.\mathrm{C}^{\wedge} \mathrm{N}^{\wedge} \mathrm{C}\right), 7.30(\mathrm{~d}, J=9.0 \mathrm{~Hz}, 1 \mathrm{H}$, $-\mathrm{FC}_{6} \mathrm{H}_{3}-$ of $\left.\mathrm{C}^{\wedge} \mathrm{N}^{\wedge} \mathrm{C}\right), 7.26\left(\mathrm{~d}, J=8.0 \mathrm{~Hz}, 2 \mathrm{H},-\mathrm{C}_{6} \mathrm{H}_{4}-\right.$ of $\left.\mathrm{C}^{\wedge} \mathrm{N}^{\wedge} \mathrm{C}\right)$, 6.92-6.89 (m, $1 \mathrm{H},-\mathrm{F}_{2} \mathrm{C}_{6} \mathrm{H}_{2}-$ of $\left.\mathrm{C}^{\wedge} \mathrm{N}^{\wedge} \mathrm{C}\right), 6.79-6.77(\mathrm{~m}, 1 \mathrm{H}$, $-\mathrm{FC}_{6} \mathrm{H}_{3}-$ of $\left.\mathrm{C}^{\wedge} \mathrm{N}^{\wedge} \mathrm{C}\right), 6.73-6.68\left(\mathrm{~m}, 1 \mathrm{H},-\mathrm{FC}_{6} \mathrm{H}_{3}-\right.$ of $\left.\mathrm{C}^{\wedge} \mathrm{N}^{\wedge} \mathrm{C}\right), 1.40$ (s, 9H, ${ }^{t} \mathrm{Bu},-\mathrm{C}_{6} \mathrm{H}_{4}-$ of $\left.\mathrm{C}^{\wedge} \mathrm{N}^{\wedge} \mathrm{C}\right), 1.38$ (s, 9H, $\left.-{ }^{t} \mathrm{Bu},-\mathrm{C}_{6} \mathrm{H}_{4}{ }^{t} \mathrm{Bu}-p\right)$. ${ }^{13} \mathrm{C}\left\{{ }^{1} \mathrm{H}\right\}$ NMR (150 MHz, THF-d $\left.{ }_{8}, \delta / \mathrm{ppm}\right): \delta$ 168.87, 168.77, 167.32 , 167.25, 166.28, 164.59, 164.38, 164.31, 163.12, 162.77, $162.72,162.70,155.79,154.81,153.66,153.60,153.54,153.48$, $147.57,147.43,147.28,146.49,146.48,140.50,140.47,135.32$, $133.88,128.44,128.39,128.24,126.96,125.98,122.17,122.04$, $116.39,116.25,114.16,144.00,110.01,109.99,109.86,109.84$, 106.69, 106.53, 106.47, 106.31, 35.57, 34.90, 32.00, 31.58. ${ }^{19} \mathrm{~F}$ $\left\{{ }^{1} \mathrm{H}\right\}$ NMR $\left(470 \mathrm{MHz}, \mathrm{CD}_{2} \mathrm{Cl}_{2}, 298 \mathrm{~K}\right.$, relative to $\mathrm{CF}_{3} \mathrm{COOH}$, $\delta / \mathrm{ppm}): \delta-86.87,-107.74,-113.42$. Positive ESI-MS: $m / z 746.2$ $[\mathrm{M}+\mathrm{H}]^{+}$. Elemental analyses: found (\%): C 59.24, H 4.82, N 1.75. Calcd for $\mathrm{AuC}_{37} \mathrm{H}_{33} \mathrm{NF}_{3}$ : C 59.60, H 4.46, N 1.88 .

Complex 4. Yield: $80 \mathrm{mg}, 42 \%$. ${ }^{1} \mathrm{H}$ NMR $(500 \mathrm{MHz}$, acetone$\left.\mathrm{d}_{6}, 298 \mathrm{~K}, \delta / \mathrm{ppm}\right): \delta 8.38\left(\mathrm{~s}, 2 \mathrm{H},-\right.$ py of $\left.\mathrm{C}^{\wedge} \mathrm{N}^{\wedge} \mathrm{C}\right), 8.03(\mathrm{~d}, J=$ $8.5 \mathrm{~Hz}, 2 \mathrm{H},-\mathrm{C}_{6} \mathrm{H}_{4}-$ of $\left.\mathrm{C}^{\wedge} \mathrm{N}^{\wedge} \mathrm{C}\right), 7.81-7.79\left(\mathrm{~m}, 2 \mathrm{H},-\mathrm{F}_{2} \mathrm{C}_{6} \mathrm{H}_{2}-\right.$ of $\left.\mathrm{C}^{\wedge} \mathrm{N}^{\wedge} \mathrm{C}\right), 7.67\left(\mathrm{~d}, J=8.5 \mathrm{~Hz}, 2 \mathrm{H},-\mathrm{C}_{6} \mathrm{H}_{4}-\right.$ of $\left.\mathrm{C}^{\wedge} \mathrm{N}^{\wedge} \mathrm{C}\right), 7.44(\mathrm{~d}, J=$ $\left.8.0 \mathrm{~Hz}, 2 \mathrm{H},-\mathrm{C}_{6} \mathrm{H}_{4}{ }^{t} \mathrm{Bu}-p\right), 7.16\left(\mathrm{~d}, J=8.0 \mathrm{~Hz}, 2 \mathrm{H},-\mathrm{C}_{6} \mathrm{H}_{4}{ }^{t} \mathrm{Bu}-p\right)$,
6.82-6.65 (m, 2H, $-\mathrm{F}_{2} \mathrm{C}_{6} \mathrm{H}_{2}-$ of $\left.\mathrm{C}^{\wedge} \mathrm{N}^{\wedge} \mathrm{C}\right), 1.41\left(\mathrm{~s}, 9 \mathrm{H},{ }^{t} \mathrm{Bu},-\mathrm{C}_{6} \mathrm{H}_{4}-\right.$ of $\left.\mathrm{C}^{\wedge} \mathrm{N}^{\wedge} \mathrm{C}\right), 1.35$ (s, 9H, $\left.{ }^{t} \mathrm{Bu},-\mathrm{C}_{6} \mathrm{H}_{4}{ }^{t} \mathrm{Bu}-p\right) .{ }^{13} \mathrm{C}\left\{{ }^{1} \mathrm{H}\right\}$ NMR (150 MHz, THF-d $\left.\mathrm{d}_{8}, \delta / \mathrm{ppm}\right): \delta 168.12,168.02,166.15,166.05,163.60$, $163.51,161.79,161.57,155.03,154.12,152.33,152.25,152.20$, 152.12 , 145.82, 143.25, 134.16, 132.86, 127.41, 126.10, 124.33, 116.36, 109.13, 108.97, 106.33, 106.14, 106.07, 105.88, 34.69, 33.87, 31.17, 30.65. ${ }^{19} \mathrm{~F}\left\{{ }^{1} \mathrm{H}\right\} \mathrm{NMR}\left(470 \mathrm{MHz}, \mathrm{CDCl}_{3}, 298 \mathrm{~K}\right.$, relative to $\left.\mathrm{CF}_{3} \mathrm{COOH}, \delta / \mathrm{ppm}\right): \delta-87.42,-112.24$. Positive ESI-MS: $\mathrm{m} / \mathrm{z}$ $764.2[\mathrm{M}+\mathrm{H}]^{+}$. Elemental analyses: found (\%): C 58.17, $\mathrm{H} 4.42, \mathrm{~N}$ 1.83. Calcd for $\mathrm{AuC}_{37} \mathrm{H}_{32} \mathrm{NF}_{4}$ : C 58.20, $\mathrm{H} 4.22, \mathrm{~N} 1.83$.

Complex 5. Yield: $400 \mathrm{mg}, 47 \% .{ }^{1} \mathrm{H}$ NMR $\left(500 \mathrm{MHz}, \mathrm{CDCl}_{3}\right.$, $298 \mathrm{~K}$, relative to $\left.\mathrm{Me}_{4} \mathrm{Si}, \delta / \mathrm{ppm}\right): \delta 7.76(\mathrm{~d}, J=1.0 \mathrm{~Hz}, 1 \mathrm{H},-$ py of $\left.\mathrm{C}^{\wedge} \mathrm{N}^{\wedge} \mathrm{C}\right), 7.73-7.70\left(\mathrm{~m}, 2 \mathrm{H},-\right.$ py and $-\mathrm{C}_{6} \mathrm{H}_{3} \mathrm{CF}_{3}-$ of $\left.\mathrm{C}^{\wedge} \mathrm{N}^{\wedge} \mathrm{C}\right), 7.64(\mathrm{~d}$, $\left.J=6.5 \mathrm{~Hz}, 2 \mathrm{H},-\mathrm{C}_{6} \mathrm{H}_{4}{ }^{t} \mathrm{Bu}-p\right), 7.59\left(\mathrm{~d}, J=6.5 \mathrm{~Hz}, 2 \mathrm{H},-\mathrm{C}_{6} \mathrm{H}_{4}{ }^{t} \mathrm{Bu}-p\right)$, 7.46-7.44 (m, 3H, $-\mathrm{C}_{6} \mathrm{H}_{3} \mathrm{CF}_{3}-$ and $-\mathrm{C}_{6} \mathrm{H}_{4}-$ of $\left.\mathrm{C}^{\wedge} \mathrm{N}^{\wedge} \mathrm{C}\right), 7.35$ (s, $1 \mathrm{H}$, $-\mathrm{C}_{6} \mathrm{H}_{3} \mathrm{CF}_{3}-$ of $\left.\mathrm{C}^{\wedge} \mathrm{N}^{\wedge} \mathrm{C}\right), 7.27$ (d, $2 \mathrm{H}, J=8.0 \mathrm{~Hz},-\mathrm{C}_{6} \mathrm{H}_{4}-$ of $\left.\mathrm{C}^{\wedge} \mathrm{N}^{\wedge} \mathrm{C}\right)$, 7.23-7.21 (m, $1 \mathrm{H},-\mathrm{F}_{2} \mathrm{C}_{6} \mathrm{H}_{2}-$ of $\left.\mathrm{C}^{\wedge} \mathrm{N}^{\wedge} \mathrm{C}\right), 6.71-6.68(\mathrm{~m}, 1 \mathrm{H}$,

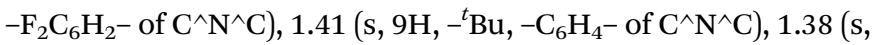
$\left.9 \mathrm{H},{ }^{t} \mathrm{Bu},-\mathrm{C}_{6} \mathrm{H}_{4}{ }^{t} \mathrm{Bu}-p\right) .{ }^{13} \mathrm{C}\left\{{ }^{1} \mathrm{H}\right\}$ NMR (125 MHz, $\left.\mathrm{CDCl}_{3}, \delta / \mathrm{ppm}\right)$ : $\delta$ 168.20, 168.11, 166.26, 166.17, 165.14, 165.11, 163.36, 163.27, $161.93,161.90,161.58,161.41,161.31,155.18,154.43,152.19$, $151.71,151.64,151.56,151.50,147.37,146.71,146.36,138.62$, $138.59,134.19,132.76,131.34,131.32,127.09$, 126.51, 125.49, 124.63 , 123.61, 123.58, 116.12, 116.06, 108.99, 108.97, 108.82, 108.79, 106.90, 106.72, 106.64, 106.46, 34.97, 34.29, 31.51, 31.24. ${ }^{19} \mathrm{~F}\left\{{ }^{1} \mathrm{H}\right\} \mathrm{NMR}\left(470 \mathrm{MHz}, \mathrm{CDCl}_{3}\right.$, relative to $\left.\mathrm{CF}_{3} \mathrm{COOH}, \delta / \mathrm{ppm}\right)$ : $\delta-63.02,-85.75,-112.50$. Positive ESI-MS: $m / z$ 796.2 $[\mathrm{M}+\mathrm{H}]^{+}$. Elemental analyses: found (\%): C 57.57, H 4.37, N 1.59. Calcd for $\mathrm{AuC}_{38} \mathrm{H}_{33} \mathrm{NF}_{5}$ : C 57.36, $\mathrm{H}$ 4.18, N 1.76.

Complex 6. Yield: $110 \mathrm{mg}, 44 \% .{ }^{1} \mathrm{H} \mathrm{NMR}\left(500 \mathrm{MHz}, \mathrm{CDCl}_{3}\right.$, $298 \mathrm{~K}$, relative to $\left.\mathrm{Me}_{4} \mathrm{Si}, \delta / \mathrm{ppm}\right): \delta 7.76\left(\mathrm{~s}, 2 \mathrm{H},-\right.$ py of $\left.\mathrm{C}^{\wedge} \mathrm{N}^{\wedge} \mathrm{C}\right)$, $7.72\left(\mathrm{~d}, J=8.0 \mathrm{~Hz}, 2 \mathrm{H},-\mathrm{C}_{6} \mathrm{H}_{3} \mathrm{CF}_{3}-\right.$ of $\left.\mathrm{C}^{\wedge} \mathrm{N}^{\wedge} \mathrm{C}\right), 7.67-7.66(\mathrm{~m}, 2 \mathrm{H}$, $-\mathrm{C}_{6} \mathrm{H}_{3} \mathrm{CF}_{3}-$ of $\left.\mathrm{C}^{\wedge} \mathrm{N}^{\wedge} \mathrm{C}\right), 7.62-7.57\left(\mathrm{~m}, 4 \mathrm{H},-\mathrm{C}_{6} \mathrm{H}_{4}-\right.$ of $\left.\mathrm{C}^{\wedge} \mathrm{N}^{\wedge} \mathrm{C}\right)$, 7.47-7.45 (m, $4 \mathrm{H},-\mathrm{C}_{6} \mathrm{H}_{3} \mathrm{CF}_{3}-$ of $\mathrm{C}^{\wedge} \mathrm{N}^{\wedge} \mathrm{C}$ and $\left.-\mathrm{C}_{6} \mathrm{H}_{4}{ }^{t} \mathrm{Bu}-p\right), 7.35$ (d, $\left.J=8.5 \mathrm{~Hz}, 2 \mathrm{H},-\mathrm{C}_{6} \mathrm{H}_{4}{ }^{t} \mathrm{Bu}-p\right), 1.42\left(\mathrm{~s}, 18 \mathrm{H},-{ }^{t} \mathrm{Bu},-\mathrm{C}_{6} \mathrm{H}_{4}-\right.$ of $\mathrm{C}^{\wedge} \mathrm{N}^{\wedge} \mathrm{C}$ and $\left.-\mathrm{C}_{6} \mathrm{H}_{4}{ }^{t} \mathrm{Bu}-p\right) .{ }^{13} \mathrm{C}\left\{{ }^{1} \mathrm{H}\right\}$ NMR (150 MHz, $\mathrm{CDCl}_{3}, \delta /$ ppm): $\delta 168.19,161.84,155.19,154.37,152.76,147.96,142.36$, 134.22 , 133.04, 132.18, 131.97, 131.94, 127.10, 126.46, 126.25, $125.53,125.22,124.67,123.46,123.44,123.41,116.14,34.95$, 34.41, 31.49, 31.23. ${ }^{19} \mathrm{~F}\left\{{ }^{1} \mathrm{H}\right\}$ NMR (470 $\mathrm{MHz} \mathrm{CDCl}_{3}, 298 \mathrm{~K}$, relative to $\left.\mathrm{CF}_{3} \mathrm{COOH}, \delta / \mathrm{ppm}\right): \delta-62.81$. Positive ESI-MS: $\mathrm{m} / \mathrm{z}$ 828.2 $[\mathrm{M}+\mathrm{H}]^{+}$. Elemental analyses: found (\%): C 56.63, H 4.18, N 1.52. Calcd for $\mathrm{AuC}_{39} \mathrm{H}_{34} \mathrm{NF}_{6}$ : C 56.60, H 4.14, N 1.69.

Complex 7. Yield: $320 \mathrm{mg}, 48 \% .{ }^{1} \mathrm{H} \mathrm{NMR}\left(500 \mathrm{MHz}, \mathrm{CDCl}_{3}\right.$, $298 \mathrm{~K}$, relative to $\left.\mathrm{Me}_{4} \mathrm{Si}, \delta / \mathrm{ppm}\right): \delta 7.58(\mathrm{~d}, J=8.5 \mathrm{~Hz}, 2 \mathrm{H}$, $-\mathrm{C}_{6} \mathrm{H}_{3} \mathrm{OCF}_{3}-$ of $\left.\mathrm{C}^{\wedge} \mathrm{N}^{\wedge} \mathrm{C}\right), 7.55-7.50\left(\mathrm{~m}, 6 \mathrm{H},-\right.$ py and $-\mathrm{C}_{6} \mathrm{H}_{4}-$ of $\left.\mathrm{C}^{\wedge} \mathrm{N}^{\wedge} \mathrm{C}\right), 7.38\left(\mathrm{~d}, J=8.5 \mathrm{~Hz}, 2 \mathrm{H},-\mathrm{C}_{6} \mathrm{H}_{4}{ }^{t} \mathrm{Bu}-p\right), 7.31(\mathrm{~d}, J=8.5 \mathrm{~Hz}$, $\left.2 \mathrm{H},-\mathrm{C}_{6} \mathrm{H}_{4}{ }^{t} \mathrm{Bu}-p\right)$, 7.18-7.17 (m, $2 \mathrm{H},-\mathrm{C}_{6} \mathrm{H}_{3} \mathrm{OCF}_{3}-$ of $\left.\mathrm{C}^{\wedge} \mathrm{N}^{\wedge} \mathrm{C}\right)$, 6.98-6.96 (m, 2H, $-\mathrm{C}_{6} \mathrm{H}_{3} \mathrm{OCF}_{3}-$ of $\left.\mathrm{C}^{\wedge} \mathrm{N}^{\wedge} \mathrm{C}\right), 1.40\left(\mathrm{~s}, 9 \mathrm{H},{ }^{t} \mathrm{Bu}\right.$, $-\mathrm{C}_{6} \mathrm{H}_{4}-$ of $\left.\mathrm{C}^{\wedge} \mathrm{N}^{\wedge} \mathrm{C}\right), 1.37$ (s, 9H, $\left.{ }^{t} \mathrm{Bu},-\mathrm{C}_{6} \mathrm{H}_{4}{ }^{t} \mathrm{Bu}-p\right) .{ }^{13} \mathrm{C}\left\{{ }^{1} \mathrm{H}\right\} \mathrm{NMR}$ (125 MHz, $\left.\mathrm{CDCl}_{3}, \delta / \mathrm{ppm}\right): \delta$ 170.19, 161.86, 154.87, 154.24, 151.32, 147.91, 147.83, 142.67, 134.49, 133.23, 127.29, 127.15, $126.46,126.24,121.60,119.55,118.00,115.10,35.03,34.50$, 31.63, 31.35. ${ }^{19} \mathrm{~F}\left\{{ }^{1} \mathrm{H}\right\}$ NMR (470 $\mathrm{MHz}, \mathrm{CDCl}_{3}$, relative to $\mathrm{CF}_{3^{-}}$ $\mathrm{COOH}, \delta / \mathrm{ppm}): \delta-57.16$. Positive FAB-MS: $m / z$ 860.2 $[\mathrm{M}+\mathrm{H}]^{+}$. Elemental analyses: found (\%): $\mathrm{C} 54.47, \mathrm{H} 4.15, \mathrm{~N} 1.47$. Calcd for $\mathrm{AuC}_{39} \mathrm{H}_{34} \mathrm{NO}_{2} \mathrm{~F}_{6}$ : C 54.49, H 3.99, N 1.63. 


\section{Conflicts of interest}

There are no conflicts to declare.

\section{Acknowledgements}

V. W.-W. Y. acknowledges UGC funding provided by The University of Hong Kong (HKU) for supporting the Electrospray Ionization Quadrupole Time-of-Flight Mass Spectrometry Facilities under the Support for Interdisciplinary Research in Chemical Science, the HKU Development Fund and Dr Hui Wai Haan Fund for funding the X-Ray Diffractometer Facilities, and the support from The University of Hong Kong under the Research Committee (URC) Strategically Oriented Research Theme on Functional Materials for Molecular Electronics. The work described in this paper was fully supported by a grant from the University Grants Committee Areas of Excellence (AoE) Scheme from the Hong Kong Special Administrative Region, China (Project No. AoE/P-03/08). W.-K. K. acknowledges the receipt of postgraduate studentships from HKU. L. H.-Y. Lo and P. P.-L. Tang are acknowledged for their assistance in the preparation of precursor gold(III) complexes and solutionprocessable OLED fabrication respectively.

\section{References}

1 M. A. Baldo, D. F. O'Brien, Y. You, A. Shoustikov, S. Sibley, M. E. Thompson and S. R. Forrest, Highly Efficient Phosphorescent Emission from Organic Electroluminescent Devices, Nature, 1998, 395, 151-154.

2 B. W. D'Andrade and S. R. Forrest, White Organic LightEmitting Devices for Solid-State Lighting, Adv. Mater. (Weinheim, Ger.), 2004, 16, 1585-1595.

3 C. W. Tang and S. A. Vanslyke, Organic Electroluminescent Diodes, Appl. Phys. Lett., 1987, 51, 913-915.

4 Y. Seino, S. Inomata, H. Sasabe, Y. J. Pu and J. Kido, HighPerformance Green OLEDs Using Thermally Activated Delayed Fluorescence with a Power Efficiency of over 100 $\operatorname{lm} \mathrm{W}(-1)$, Adv. Mater., 2016, 28, 2638-2643.

5 L. Xiao, Z. Chen, B. Qu, J. Luo, S. Kong, Q. Gong and J. Kido, Recent Progresses on Materials for Electrophosphorescent Organic Light-Emitting Devices, Adv. Mater. (Weinheim, Ger.), 2011, 23, 926-952.

6 S. O. Jeon, S. E. Jang, H. S. Son and J. Y. Lee, External Quantum Efficiency Above $20 \%$ in Deep Blue Phosphorescent Organic Light-Emitting Diodes, Adv. Mater. (Weinheim, Ger.), 2011, 23, 1436-1441.

7 J. Lee, H.-F. Chen, T. Batagoda, C. Coburn, P. I. Djurovich, M. E. Thompson and S. R. Forrest, Deep Blue Phosphorescent Organic Light-Emitting Diodes with Very High Brightness and Efficiency, Nat. Mater., 2016, 15, 92-98.

8 T. Miwa, S. Kubo, K. Shizu, T. Komino, C. Adachi and H. Kaji, Blue Organic Light-Emitting Diodes Realizing External Quantum Efficiency over $25 \%$ Using Thermally Activated Delayed Fluorescence Emitters, Sci. Rep., 2017, 7, 284.

9 T. B. Fleetham, L. Huang, K. Klimes, J. Brooks and J. Li, Tetradentate Pt(II) Complexes with 6-Membered Chelate
Rings: A New Route for Stable and Efficient Blue Organic Light Emitting Diodes, Chem. Mater., 2016, 28, 3276-3282.

10 G. Zhou, W. Y. Wong and X. Yang, New Design Tactics in OLEDs Using Functionalized 2-Phenylpyridine-Type Cyclometalates of Iridium(III) and Platinum(II), Chem. Asian J., 2011, 6, 1706-1727.

11 S. C. Kui, P. K. Chow, G. Cheng, C.-C. Kwok, C.-L. Kwong, K. H. Low and C.-M. Che, Robust Phosphorescent Platinum(II) Complexes with Tetradentate $\quad \mathrm{O}^{\wedge} \mathrm{N}^{\wedge} \mathrm{C}^{\wedge} \mathrm{N}$ Ligands: High Efficiency OLEDs with Excellent Efficiency Stability, Chem. Commun., 2013, 49, 1497-1499.

12 C.-W. Hsu, Y. Zhao, H.-H. Yeh, C.-W. Lu, C. Fan, Y. Hu, N. Robertson, G.-H. Lee, X. W. Sun and Y. Chi, Efficient Pt(II) Emitters Assembled from Neutral Bipyridine and Dianionic Bipyrazolate: Designs, Photophysical Characterization and the Fabrication of Non-Doped OLEDs, J. Mater. Chem. C, 2015, 3, 10837-10847.

13 J. H. Lee, G. Sarada, C. K. Moon, W. Cho, K. H. Kim, Y. G. Park, J. Y. Lee, S. H. Jin and J. J. Kim, Finely Tuned Blue Iridium Complexes with Varying Horizontal Emission Dipole Ratios and Quantum Yields for Phosphorescent Organic LightEmitting Diodes, Adv. Opt. Mater., 2015, 3, 211-220.

14 C. Adachi, R. C. Kwong, P. Djurovich, V. Adamovich, M. A. Baldo, M. E. Thompson and S. R. Forrest, Endothermic Energy Transfer: A Mechanism for Generating Very Efficient High-Energy Phosphorescent Emission in Organic Materials, Appl. Phys. Lett., 2001, 79, 2082-2084.

15 R. J. Holmes, B. W. D'Andrade, S. R. Forrest, X. Ren, J. Li and M. E. Thompson, Efficient, Deep-Blue Organic Electrophosphorescence by Guest Charge Trapping, Appl. Phys. Lett., 2003, 83, 3818.

16 T. Sajoto, P. I. Djurovich, A. Tamayo, M. Yousufuddin, R. Bau, M. E. Thompson, R. J. Holmes and S. R. Forrest, Blue and Near-UV Phosphorescence from Iridium Complexes with Cyclometalated Pyrazolyl or $N$-Heterocyclic Carbene Ligands, Inorg. Chem., 2005, 44, 7992-8003.

17 J. H. Seo, G. Y. Kim, J. H. Kim, J. S. Park, B. M. Seo, K. H. Lee, S. S. Yoon and Y. K. Kim, Highly Efficient Deep-Blue Phosphorescent Organic Light-Emitting Diodes Using Iridium(III) Bis[(5-cyano-4-fluorophenyl)pyridinato-N,C 2' ] picolinate as an Emitter, Jpn. J. Appl. Phys., 2009, 48, 082103. 18 C.-H. Hsieh, F.-I. Wu, C.-H. Fan, M.-J. Huang, K.-Y. Lu, P.-Y. Chou, Y.-H. O. Yang, S.-H. Wu, I. C. Chen, S.-H. Chou, K.-T. Wong and C.-H. Cheng, Design and Synthesis of Iridium Bis(carbene) Complexes for Efficient Blue Electrophosphorescence, Chem. - Eur. J., 2011, 17, 9180-9187.

19 H.-J. Seo, K.-M. Yoo, M. Song, J. S. Park, S.-H. Jin, Y. I. Kim and J.-J. Kim, Deep-Blue Phosphorescent Iridium Complexes with Picolinic Acid $N$-Oxide as the Ancillary Ligand for High Efficiency Organic Light-Emitting Diodes, Org. Electron., 2010, 11, 564-572.

20 X.-C. Hang, T. Fleetham, E. Turner, J. Brooks and J. Li, Highly Efficient Blue-Emitting Cyclometalated Platinum(II) Complexes by Judicious Molecular Design, Angew. Chem., Int. Ed., 2013, 52, 6753-6756.

21 C.-H. Lee, M.-C. Tang, Y.-C. Wong, M.-Y. Chan and V. W.-W. Yam, Sky-Blue-Emitting Dendritic Alkynylgold(III) 
Complexes for Solution-Processable Organic Light-Emitting Devices, J. Am. Chem. Soc., 2017, 139, 10539-10550.

22 K. M.-C. Wong, M. M.-Y. Chan and V. W.-W. Yam, Supramolecular Assembly of Metal-Ligand Chromophores for Sensing and Phosphorescent OLED Applications, Adv. Mater. (Weinheim, Ger.), 2014, 26, 5558-5568.

23 K. M.-C. Wong, X. Zhu, L.-L. Hung, N. Zhu, V. W.-W. Yam and H.-S. Kwok, High-Efficiency Green Organic LightEmitting Devices Utilizing Phosphorescent Biscyclometalated Alkynylgold(III) Complexes, Chem. Commun., 2005, 2906-2908.

24 V. K.-M. Au, K. M.-C. Wong, D. P.-K. Tsang, M.-Y. Chan, N. Zhu and V. W.-W. Yam, High-Efficiency Green Organic Light-Emitting Devices Utilizing Phosphorescent Biscyclometalated Alkynylgold(III) Complexes, J. Am. Chem. Soc., 2010, 132, 14273-14278.

25 B. Y.-W. Wong, H.-L. Wong, Y.-C. Wong, M.-Y. Chan and V. W.-W. Yam, Versatile Synthesis of Luminescent Tetradentate Cyclometalated Alkynylgold(III) Complexes and Their Application in Solution-Processable Organic Light-Emitting Devices, Angew. Chem., Int. Ed., 2016, 56, 302-305.

26 V. K.-M. Au, D. P.-K. Tsang, K. M.-C. Wong, M.-Y. Chan, N. Zhu and V. W.-W. Yam, Functionalized BisCyclometalated Alkynylgold(III) Complexes: Synthesis, Characterization, Electrochemistry, Photophysics, Photochemistry, and Electroluminescence Studies, Inorg. Chem., 2013, 52, 12713-12725.

27 M.-C. Tang, D. P.-K. Tsang, M. M.-Y. Chan, K. M.-C. Wong and V. W.-W. Yam, Dendritic Luminescent Gold(III) Complexes for Highly Efficient Solution-Processable Organic Light-Emitting Devices, Angew. Chem., Int. Ed., 2013, 52, 446-449.

28 M.-C. Tang, C. K.-M. Chan, D. P.-K. Tsang, Y.-C. Wong, M. M.-Y. Chan, K. M.-C. Wong and V. W.-W. Yam, Saturated Red-Light-Emitting Gold(III) Triphenylamine Dendrimers for Solution-Processable Organic LightEmitting Devices, Chem. - Eur. J., 2014, 20, 1523315241.

29 M.-C. Tang, D. P.-K. Tsang, Y.-C. Wong, M.-Y. Chan, K. M.-C. Wong and V. W.-W. Yam, Bipolar Gold(III) Complexes for Solution-Processable Organic Light-Emitting Devices with a Small Efficiency Roll-Off, J. Am. Chem. Soc., 2014, 136, 17861-17868.

30 G. Cheng, K. T. Chan, W.-P. To and C.-M. Che, Color Tunable Organic Light-Emitting Devices with External Quantum Efficiency over $20 \%$ based on Strongly Luminescent Gold(III) Complexes having Long-Lived Emissive Excited States, Adv. Mater. (Weinheim, Ger.), 2014, 26, 2540-2546.

31 K. T. Chan, G. S. M. Tong, Q. Wan, G. Cheng, C. Yang and C.-M. Che, Strongly Luminescent Cyclometalated Gold(III) Complexes Supported by Bidentate Ligands Displaying Intermolecular Interactions and Tunable Emission Energy, Chem. - Asian J., 2017, 12, 2104-2120.

32 W.-P. To, D. Zhou, G. S. M. Tong, G. Cheng, C. Yang and C.-M. Che, Highly Luminescent Pincer Gold(III) Aryl Emitters: Thermally Activated Delayed Fluorescence and
Solution-Processed OLEDs, Angew. Chem., Int. Ed., 2017, 56, 14036-14041.

33 D.-A. Roşca, D. A. Smith and M. Bochmann, Cyclometallated Gold(III) Hydroxides as Versatile Synthons for $\mathrm{Au}-\mathrm{N}, \mathrm{Au}-\mathrm{C}$ Complexes and Luminescent Compounds, Chem. Commun., 2012, 48, 7247-7249.

34 C. Bronner and O. S. Wenger, Luminescent Cyclometalated Gold(III) Complexes, Dalton Trans., 2011, 40, 12409-12420.

35 M.-C. Tang, C.-H. Lee, S.-L. Lai, M. Ng, M.-Y. Chan and V. W.-W. Yam, Versatile Design Strategy for Highly Luminescent Vacuum-Evaporable and Solution-Processable Tridentate Gold(III) Complexes with Monoaryl Auxiliary Ligands and Their Applications for Phosphorescent Organic Light Emitting Devices, J. Am. Chem. Soc., 2017, 139, 9341-9349. 36 V. W.-W. Yam, K. M.-C. Wong, L.-L. Hung and N. Zhu, Luminescent Gold(III) Alkynyl Complexes: Synthesis, Structural Characterization, and Luminescence Properties, Angew. Chem., Int. Ed., 2005, 44, 3107-3110.

37 K. M.-C. Wong, L.-L. Hung, W. H. Lam, N. Zhu and V. W.-W. Yam, A Class of Luminescent Cyclometalated Alkynylgold(III) Complexes: Synthesis, Characterization, and Electrochemical, Photophysical, and Computational Studies of $\left[\mathrm{Au}\left(\mathrm{C}^{\wedge} \mathrm{N}^{\wedge} \mathrm{C}\right)(\mathrm{C} \equiv \mathrm{CR})\right]\left(\mathrm{C}^{\wedge} \mathrm{N}^{\wedge} \mathrm{C}=\kappa^{3} \mathrm{C}, \mathrm{N}, \mathrm{C}\right.$ Biscyclometalated 2,6-Diphenylpyridyl), J. Am. Chem. Soc., 2007, 129, 4350-4365.

38 G. S. M. Tong, K. T. Chan, X. Chang and C.-M. Che, Theoretical Studies on the Photophysical Properties of Luminescent Pincer Gold(III) Arylacetylide Complexes: the Role of [Small Pi]-Conjugation at the C-deprotonated $\left[\mathrm{C}^{\wedge} \mathrm{N}^{\wedge} \mathrm{C}\right]$ Ligand, Chem. Sci., 2015, 6, 3026-3037.

39 K. Li, G. S. M. Tong, Q. Wan, G. Cheng, W.-Y. Tong, W.-H. Ang, W.-L. Kwong and C.-M. Che, Highly Phosphorescent Platinum(II) Emitters: Photophysics, Materials And Biological Applications, Chem. Sci., 2016, 7, 1653-1673.

40 M. De Jong, L. Seijo, A. Meijerink and F. T. Rabouw, Resolving the Ambiguity in the Relation between Stokes Shift and Huang-Rhys Parameter, Phys. Chem. Chem. Phys., 2015, 17, 16959-16969.

41 G. S. Remya and C. H. Suresh, Quantification and Classification of Substituent Effects in Organic Chemistry: a Theoretical Molecular Electrostatic Potential Study, Phys. Chem. Chem. Phys., 2016, 18, 20615-20626.

42 V. W.-W. Yam, S. W.-K. Choi, T.-F. Lai and W.-K. Lee, Syntheses, Crystal Structures and Photophysics of Organogold(III) Diimine Complexes, J. Chem. Soc., Dalton Trans., 1993, 1001-1002.

43 K.-H. Wong, K.-K. Cheung, M. C.-W. Chan and C.-M. Che, Application of 2,6-Diphenylpyridine as a Tridentate $\left[\mathrm{C}^{\wedge} \mathrm{N}^{\wedge} \mathrm{C}\right]$ Dianionic Ligand in Organogold(III) Chemistry. Structural and Spectroscopic Properties of Monoand Binuclear Transmetalated Gold(III) Complexes, Organometallics, 1998, 17, 3505-3511.

44 G. A. Crosby and J. N. Demas, Measurement of Photoluminescence Quantum Yields. Review, J. Phys. Chem., 1971, 75, 991-1024. 